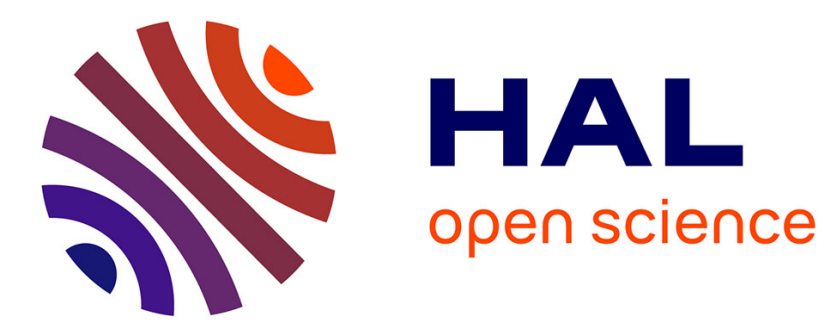

\title{
Controlling Helix Handedness in Water-Soluble Quinoline Oligoamide Foldamers
}

Simon J. Dawson, Ádám Mészáros, Lilla Pethö, Cinzia Colombo, Márton

Csékei, András Kotschy, Ivan Huc

\section{To cite this version:}

Simon J. Dawson, Ádám Mészáros, Lilla Pethö, Cinzia Colombo, Márton Csékei, et al.. Controlling Helix Handedness in Water-Soluble Quinoline Oligoamide Foldamers. European Journal of Organic Chemistry, 2014, 2014 (20), pp.4265-4275. 10.1002/ejoc.201402247 . hal-01509465

\section{HAL Id: hal-01509465 \\ https://hal.science/hal-01509465}

Submitted on 18 Apr 2017

HAL is a multi-disciplinary open access archive for the deposit and dissemination of scientific research documents, whether they are published or not. The documents may come from teaching and research institutions in France or abroad, or from public or private research centers.
L'archive ouverte pluridisciplinaire HAL, est destinée au dépôt et à la diffusion de documents scientifiques de niveau recherche, publiés ou non, émanant des établissements d'enseignement et de recherche français ou étrangers, des laboratoires publics ou privés. 


\title{
Controlling Helix Handedness in Water Soluble Quinoline Oligoamide Foldamers
}

\author{
Simon J. Dawson, ${ }^{[\mathrm{a}, \mathrm{b}]}$ Ádám Mészáros, ${ }^{[\mathrm{c}]}$ Lilla Pethő, ${ }^{[\mathrm{c}]}$ Cinzia Colombo, ${ }^{[\mathrm{a}, \mathrm{b}]}$ Márton Csékei, ${ }^{[\mathrm{c}]}$ \\ András Kotschy, ${ }^{*[c]}$ and Ivan Huc ${ }^{*[a, b]}$
}

Keywords: Quinoline oligoamide foldamers / Chirality / Conformational analysis / Helix handedness control

\begin{abstract}
For the purpose of biological applications, controlling the helix handedness of water soluble quinoline-based oligoamide foldamers has been investigated by the installation of chiral end groups at either the $\mathrm{C}$ - or N-terminus. This has resulted in the development of monomer units capable of unequivocally inducing helical sense without impacting on aqueous solubility.
\end{abstract}

\section{Introduction}

The chirality of secondary structures such as helices is a property fundamental to the complex molecular interactions involved in cellular processes, for example at protein-protein interfaces. The importance of diastereomeric selectivity in biological target recognition highlights the need to investigate right-handed $(P)$ or left-handed $(M)$ conformers of helical foldamers as distinct entities, as such compounds are being considered as useful ligands for biopolymer recognition. ${ }^{[1]}$ By extension the ability to reliably induce helix handedness under biocompatible conditions is a must.

Induction of handedness in helical foldamers is an attractive concept, since it allows the display of functionality in a specific one-handed array along the face of the scaffold, and thus the potential ability to recognise a particular biological surface with high selectivity. Handedness induction is inherent in peptidic foldamers since chirality is imparted by the amino acid building blocks. ${ }^{[2]}$ Aromatic amide backbones do not possess stereogenic centres and form racemic mixtures of $P$ and $M$ helices in solution. ${ }^{[3]}$ In this case, it is therefore necessary to consider other methods for the control of handedness.

Helical aromatic oligoamide foldamers, such as those consisting of 8-amino-2-quinolinecarboxylic acid (Figure 1), feature properties which make them promising candidates for the recognition of protein and nucleic acid surfaces: they adopt well defined, predictable conformations, they are medium sized (0.5-5.0 $\mathrm{kDa}$ ), they are resistant to proteolytic degradation, and have been shown to possess cell-penetrating properties. ${ }^{[4]}$ However the fact that they do not closely resemble the biological structures they mimic makes the challenge to design ligands for proteins and nucleic acids all the more difficult. One rapid method for screening quinoline oligoamides for activity against a given biological surface relies on the fact that without any stereogenic centre, short sequences

[a] Université de Bordeaux, CBMN (UMR 5248)

Institut Européen de Chimie Biologie, 2 rue Robert Escarpit, 33607 Pessac, France

E-mail: i.huc@iecb.u-bordeaux.f

[b] CNRS, CBMN (UMR5248)

[c] Servier Research Institute of Medicinal Chemistry, Záhony utca 7. Budapest, 1031, Hungary.

Supporting information for this article is available on the WWW under http://dx.doi.org/10.1002/ejoc.Xxxxxxxxx.
Furthermore, we showed that very slow helix handedness inversion in water can be taken advantage of. The incorporation of a chiral moiety possessing no handedness induction properties was shown to allow chromatographic separation of $P$ and $M$ helices as diastereoisomers having a kinetically locked handedness.
( $<5$ units) exist as a mixture of interconverting $P$ and $M$ helical conformations. If binding to a target surface is helix sense dependent, then the equilibrium will be shifted towards the preferred conformer- a process which can be monitored by induced circular dichroism (ICD). Indeed, the $P$ and $M$ helices possess opposite sign $\mathrm{CD}$ bands that cancel each other. When equilibrium deviates from a 50:50 mixture, $\mathrm{CD}$ bands emerge. This technique has recently been used to screen short quinoline oligoamide sequences tethered to human carbonic anhydrase II (HCA) via a ligand (Figure 2), identifying a sequence which not only possessed affinity for the protein surface, but also induced the formation of a novel HCA dimer. ${ }^{[5]}$ Helix handedness induction has also been observed between a fully cationic side-chain functionalized tetramer and G-quadruplex $\mathrm{DNA}^{[6]}$ and between helical capsules and their chiral guests. ${ }^{[7]}$ In the former two cases, handedness induction is not required, because the biological target itself exerts control over helix sense.
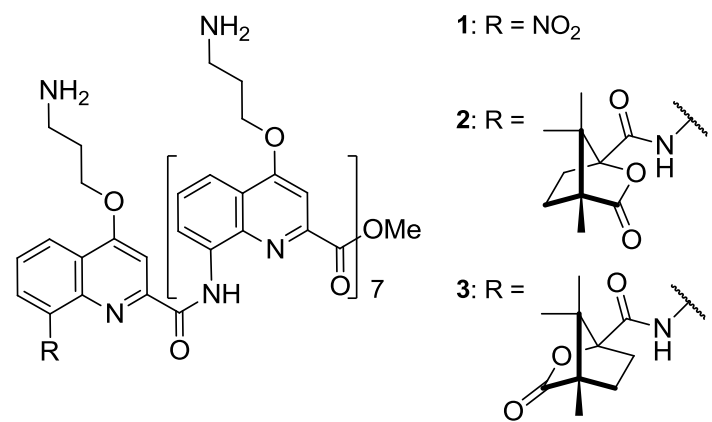

Figure 1. Cationic octamer and camphanyl inducing groups.

However, it has also been shown that the kinetics of helix handedness inversion of 8-amino-2-quinolinecarboxylic acid oligoamides slow down as strand length increases. ${ }^{[8]}$ This effect is so pronounced in protic solvents that handedness becomes kinetically stable for octameric sequences, ${ }^{[9]}$ precluding the use of the biological target as a handedness inducer. An alternative is then to induce helix handedness in the oligomer via the incorporation of a chiral unit either at an end ${ }^{[10]}$ or middle ${ }^{[11]}$ of the sequence, or by the presence of chiral side chain functionality. ${ }^{[12]}$ Both enantiomers can then be assessed independently for binding affinity to the target. 
This approach has been used in the assessment of G-quadruplex DNA binding of quinoline oligoamide foldamers. SELEX (systematic evolution of ligands by exponential enrichment) ${ }^{[13]}$ was used to identify G-rich aptamers with affinity for fully-cationic side-chain functionalized octamer (1, Figure 1$)$. The separate $P$ and $M$ helices of the octamer were then produced by installation of respectively the (1S)-(-)-camphanyl (2) or (1R)-(+)-camphanyl (3) group at the $\mathrm{N}$-terminus, ${ }^{[10 \mathrm{i}]}$ and the aptamer candidates were then re-assessed for binding, with one example indicating preference for the $M$ helix. ${ }^{[14]}$

However, quantitative induction of helix handedness (de > 99\%) is a challenging objective, and success is limited to a few cases. ${ }^{[6,10 \mathrm{i}, 15]}$ While the camphanyl group is successful in inducing handedness in aromatic oligoamide foldamers, its bulky and hydrophobic nature may be problematic with respect to water solubility of the final compound and also to the functioning of the foldamer as an efficient ligand. ${ }^{[14]}$ It was therefore clear to us that there was a need to further develop methods for controlling the helix handedness of quinoline oligoamide foldamers for applications in water.

Presented here are two methods to allow the preparation of isolated $P$ and $M$ helices of water soluble quinoline oligoamides. Firstly we investigated the concept that, since longer ( $>6$ units) are essentially kinetically 'locked' into position in aqueous conditions, the incorporation of a chiral moiety possessing no handedness induction properties could potentially allow chromatographic separation of $P$ and $M$ helices as diastereoisomers. Secondly we studied the effect of appending a chiral moiety onto position 8 of a quinoline monomer unit ( $\mathbf{Q} \mathbf{Y}$, Figure 2$)$ which could potentially allow it to act as an $\mathrm{N}$-terminal handedness inducer.

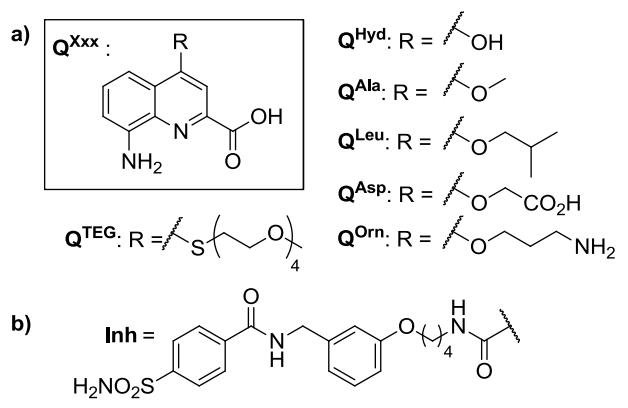

c)
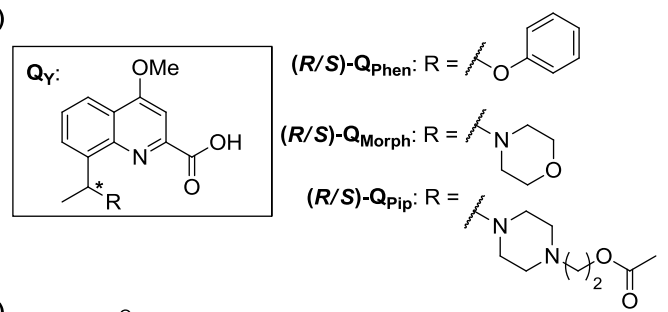

d)

4: $\mathrm{Ac}-\left(\mathrm{Q}^{\mathrm{Orn}}\right)_{8}-\mathrm{Phe}-\mathrm{OH}$

5: Inh- $Q^{\text {Leu }}-Q^{\text {Hyd }}-Q^{\text {Orn }}-Q^{\text {Asp }}-Q^{\text {Leu }}-Q^{\text {Hyd }}-Q^{\text {Orn }}-Q^{\text {Asp }}-\mathrm{Phe}-O H$

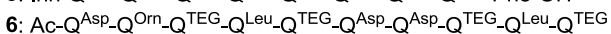

$-Q^{\mathrm{Orn}}-\mathrm{Q}^{\mathrm{Orn}}-\mathrm{Phe}-\mathrm{OH}$

7: $(R)-Q_{\text {Phen }}-Q^{\text {Leu }}-Q^{\text {Leu }}-Q^{\text {Leu }}-Q^{\text {Leu }}-$ OMe

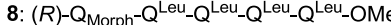

9: (S)- $Q_{\text {Morph }}-Q^{\text {Leu }}-Q^{\text {Leu }}-Q^{\text {Leu }}-Q^{\text {Leu }}-O M e$

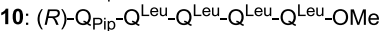

11: (S)-Q $\mathrm{Q}_{\text {Morph }}-\mathrm{Q}^{\mathrm{Orn}}-\mathrm{Q}^{\mathrm{Orn}}-\mathrm{Q}^{\mathrm{Orn}}-\mathrm{Q}^{\mathrm{Orn}}-\mathrm{OH}$

Figure 2. (a) $\mathbf{Q}^{\mathbf{X x x}}$ monomers; (b) $\mathrm{HCA}$ inhibitor structure; (c) $\mathbf{Q}_{\mathbf{Y}}$ chiral monomers (d) Summary of foldamer sequences.

These units were deliberately designed to permit solubility in both organic and aqueous conditions, allowing us to incubate the foldamer in organic solvents, taking advantage of the fast handedness inversion kinetics where equilibrium would be quickly reached, then subsequently 'locking' the handedness conformation in water.

\section{Results and Discussion}

\section{Separation of diastereoisomers arising from helix handedness}

Previously, the installation of a C-terminal phenylalanine group was found to be a poor method for controlling helix handedness in organic solvents. ${ }^{[10 \mathrm{~b}]}$ However, it was noted that the resulting $P$ and $M$ diastereoisomers possessed strikingly different retardation factors on silica gel chromatography, allowing their separation at low temperatures. Re-equilibration of each isolated diastereoisomer to the racemic mixture then rapidly occurred at room temperature. We reasoned that if the same principle could be applied on reversed-phase chromatography using water-soluble oligomers, we could take advantage of the kinetic inertness in aqueous conditions to isolate diastereoisomers which would then not racemize, provided they were exposed only to aqueous solvent mixtures.

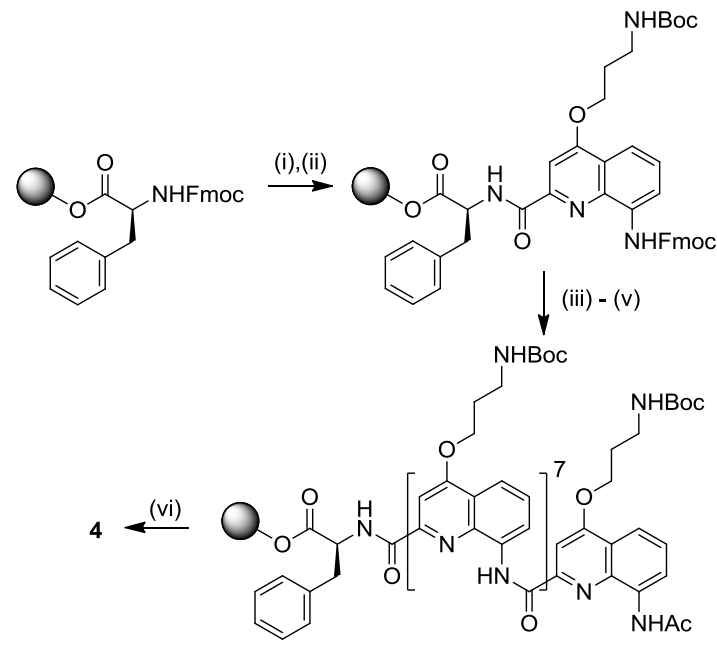

Scheme 1. SPS of fully-cationic side-chain octamer 4. Reagents and conditions: (i) $20 \% \mathrm{v} / \mathrm{v}$ piperidine in $\mathrm{DMF}, \mathrm{rt}, 10 \mathrm{~min}$, repeat once; (ii) (a) Fmoc-Q $\mathrm{Q}^{\mathrm{rn}}-\mathrm{OH}, 1$-chloro- $N, N, 2$-trimethyl-1-propenylamine, $\mathrm{CH}_{2} \mathrm{Cl}_{2}, \mathrm{rt}, 1 \mathrm{~h}$; (b) Product from (a), $i \operatorname{Pr}_{2} \mathrm{EtN}$, THF, microwave $50 \mathrm{~W}$, ramp to $50{ }^{\circ} \mathrm{C}$, hold $50{ }^{\circ} \mathrm{C}$ for $15 \mathrm{~min}$, repeat once; (iii) $20 \% \mathrm{v} / \mathrm{v}$ piperidine in DMF, rt, $10 \mathrm{~min}$, repeat twice; (iv) Repeat steps (ii)-(iii); (v) Acetyl chloride, $i \operatorname{Pr}_{2} \mathrm{EtN}, \mathrm{THF}$ microwave $50 \mathrm{~W}$, ramp to $60{ }^{\circ} \mathrm{C}$, hold $60{ }^{\circ} \mathrm{C}$ for $15 \mathrm{~min}$, repeat once; (vi) $\mathrm{TFA} / i \mathrm{Pr}_{3} \mathrm{SiH} / \mathrm{H}_{2} \mathrm{O}(95: 2.5: 2.5), \mathrm{rt}, 2 \mathrm{~h}$.

Initial work focussed on the preparation of the all-cationic sidechain functionalized octamer (4, Figure 2). Low-loading Wang resin was functionalized with Fmoc-Phe-OH using the anhydride method well documented in the literature. ${ }^{[16]}$ Fmoc deprotection was then carried out using $20 \% v / v$ piperidine in DMF and the first Fmoc- $Q^{\text {Orn }}$ unit installed via its acid chloride, formed using 1chloro- $N, N, 2$-trimethyl-1-propenylamine $\quad$ (Scheme 1). ${ }^{[17]}$ The oligoamide was then prepared using the microwave-assisted Fmoc strategy SPS previously reported by our group (see Experimental Section) ${ }^{[18]}$ Removal from the resin with concomitant side-chain Boc deprotection was subsequently carried out by treatment of the resin with $95 / 2.5 / 2.5 \mathrm{TFA} / \mathrm{H}_{2} \mathrm{O} / i \mathrm{Pr}_{3} \mathrm{SiH} v / v / v$. The crude material was analysed by RP-HPLC and indeed was found to consist of two well-separated main products (Figure 3 ) of approximate equal peak area; this was in concordance with ${ }^{1} \mathrm{H}-\mathrm{NMR}$ analysis 
demonstrating the presence of 14 amide signals, corresponding to two discrete octameric products (Figure 4a).

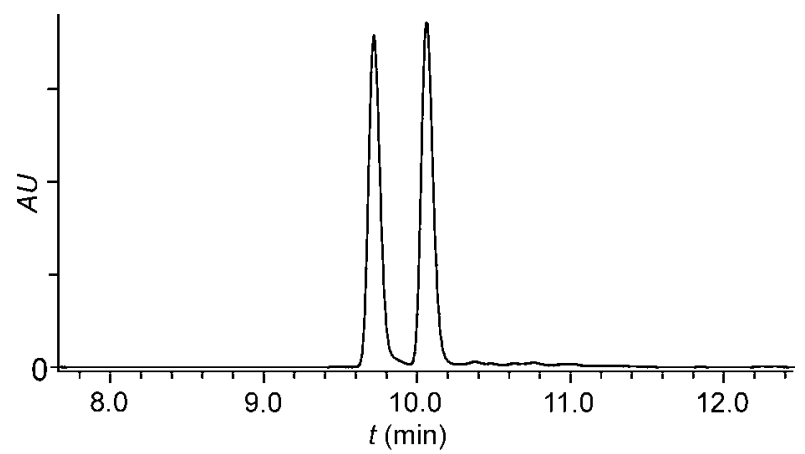

Figure 3. HPLC profile showing separation of diastereoisomers of compound 4.

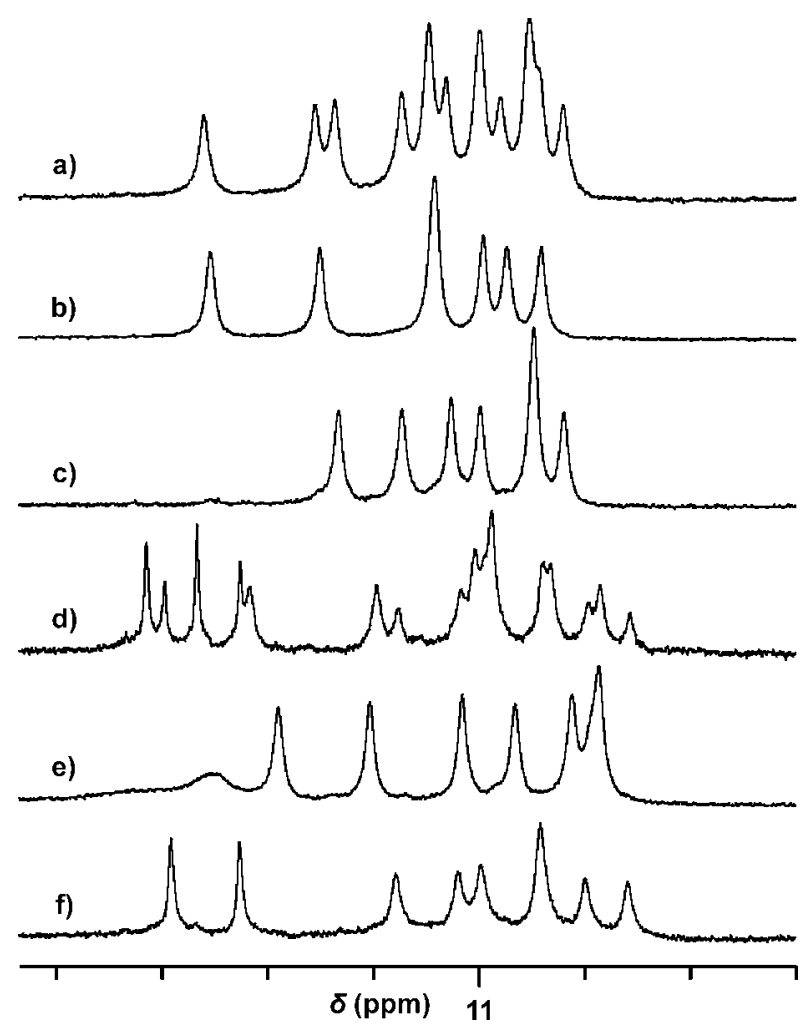

Figure 4. Carboxamide region of ${ }^{1} \mathrm{H}-\mathrm{NMR}$ for compound $\mathbf{4}$ and $\mathbf{5}$ in $d_{6}$ DMSO: (a) Crude mixture of diastereoisomers of $\mathbf{4}$ after SPS (N. B. reflects ratio of diastereoisomers in TFA cleavage mixture); (b) $\boldsymbol{P}-\mathbf{4}$ (c) $\boldsymbol{M}-\mathbf{4}$ (d) Crude mixture of diastereoisomers of $\mathbf{5}$ after SPS; (e) $\boldsymbol{P}-\mathbf{5}$ (f) $\boldsymbol{M}-\mathbf{5}$.

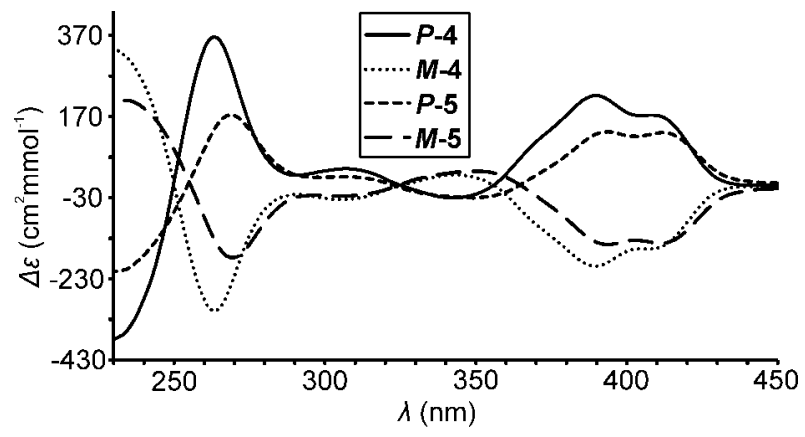

Figure 5. CD spectra of separated $P$ and $M$ diastereoisomers of compounds 4 and 5 , recorded using $50-60 \mu \mathrm{M}$ solutions.
Purification of the crude mixture was carried out using preparative RP-HPLC and analysis of each product by ${ }^{1} \mathrm{H}-\mathrm{NMR}$ and mass spectrometry confirmed identity as the expected octameric diastereoisomers. Analysis of the $\mathrm{CD}$ spectrum of each product was also important to confirm the separation of $P$ and $M$ helices. Although $P-4$ and $M-4$ helices are diastereomers and not enantiomers, the helical aromatic foldamer parts of their structures are mirror images and give rise virtually 'mirror-image' spectra of opposing sign. Indeed, CD experiments (Figure 5) showed the expected deflections at $390-410 \mathrm{~nm}$, the absorption region of the quinoline chromophores. By analogy to previous work, ${ }^{[10 b]}$ the first eluted diastereoisomer was determined to be the $P$-helix (positive band near $400 \mathrm{~nm}$ ), and the second to be the $M$-helix (negative band).

The stability of the separate diastereoisomers of compound $\mathbf{4}$ in water was assessed by HPLC, which revealed no detectable interconversion between handedness forms over a period of five days at room temperature. Unlike peptidic $\alpha$-helices which tend to be destabilised when consisting exclusively of positively charged residues, ${ }^{[19]}$ cationic aromatic oligoamide helices remain stable even when they possess multiple positive charges. This was in contrast to behaviour in DMSO, where a degree of racemization was observed after only two hours, and complete equilibration after 2-3 days (See Supporting Information). Interestingly, in DMSO it appears that the phenylalanine unit possesses a moderate ability to induce helix sense, with approximately $40 \%$ diastereomeric excess in favour of the $P$-helix.

The ability to separate $P$ and $M$ helices by using a C-terminal group allows the $\mathrm{N}$-terminus to be left free for other purposes, i.e. incorporation of functionalities. This was of interest to us with respect to recent results concerning attachment of foldamers to HCA, via an N-terminal inhibitor moiety. ${ }^{[5]}$ We thus tested the separation of helix sense diastereoisomers in the context of HCA ligands and used SPS to prepare octamer 5 that includes an $\mathrm{N}$ terminal HCA inhibitor moiety and a C-terminal Phe unit (Figure 2). Once again the crude HPLC demonstrated the presence of two major products assigned to the $P$ and $M$ helices. This was also reflected in the ${ }^{1} \mathrm{H}$-NMR spectrum (Figure $4 \mathrm{~d}$ ). Separation of the two diastereoisomers by preparative HPLC was also found to be straightforward, and both could be obtained in reasonable purity, affording analogous CD profiles to compound 4 (Figure 5). Interestingly, the order of diastereoisomer elution was the same as previously, with the $P$-helix eluting first.

The stability of the separate diastreoisomers of $\mathbf{5}$ were also assessed in aqueous conditions, although for solubility reasons this required the addition of a small proportion $(0.5-1 \%)$ of DMSO. Once again, no interconversion between handedness forms could be detected over a period of five days at room temperature (See Supporting Information).

Considering the diverse nature of the side-chains in comparison to the octamer 4 , this data suggested to us that this method could potentially be applied to a greater range of sequences. In order to determine whether this method could be used to access pure diastereoisomers of longer foldamers, we prepared 12mer 6 (Figure 2). HPLC analysis again revealed the presence of the two distinct diastereoisomers, as confirmed by MS and ${ }^{1} \mathrm{H}-\mathrm{NMR}$, but baseline separation could not be afforded with a number of different gradients, and thus in this case preparative HPLC was not attempted.

In summary, the incorporation of a chiral centre at the Cterminus afforded separable helix sense diastereoisomers of two octameric sequences possessing diverse side-chain functionality. This way, both $P$ and $M$ helices could be afforded by a single synthesis. The separated diastereoisomers were observed to be kinetically inert in water over long periods (days). This is important with respect to their use for targeting protein surfaces 
since each diastereoisomer could be assessed separately for binding via techniques such as surface plasmon resonance (SPR) without the risk of racemisation. Shorter sequences ( $\leq 5$ units) can simply be presented to the target as a racemic mixture and interactions assessed via ICD, since this is permitted by their faster handedness inversion kinetics.

\section{Induction of helix handedness via an N-terminal quinoline- based chiral building block}

We sought to further enhance our toolkit for isolating discrete helix handedness forms and to develop a method that could be applied regardless of the sequence, in particular for longer oligomers that are not all amenable to diastereomer separation. This led us to reconsider the possibility of using a terminal functional group with the ability to induce handedness. Our experience with inducing groups positioned at the $\mathrm{N}$ - and $\mathrm{C}$-termini demonstrated incomplete handedness induction, except in the case of the large and hydrophobic camphanyl group..$^{[10 \mathrm{a}-10 \mathrm{c}, 10 \mathrm{i}]} \mathrm{We}$ speculated that bringing stereogenic centres as close as possible to the quinoline backbone might offer strong inducing properties, and decided to introduce a chiral centre directly connected to position 8 of an N-terminal quinoline unit. Furthermore, we chose groups which would potentially allow solubility in a range of solvents. This way, long foldamers could be designed to allow incubation in an organic solvent where inversion kinetics are relatively fast; once induction is complete, transfer to water would then lock the conformation.

Three designs were proposed, all accessible from a common ketone precursor 12 (Scheme 2), the synthesis of which has been previously described in the literature. ${ }^{[20]}$ The QPhen monomer (Figure 2) utilised a pendant phenoxy group as steric bulk to hinder one face of the monomer unit. This was also hoped to stabilize the preferred helix formation via stacking interactions.

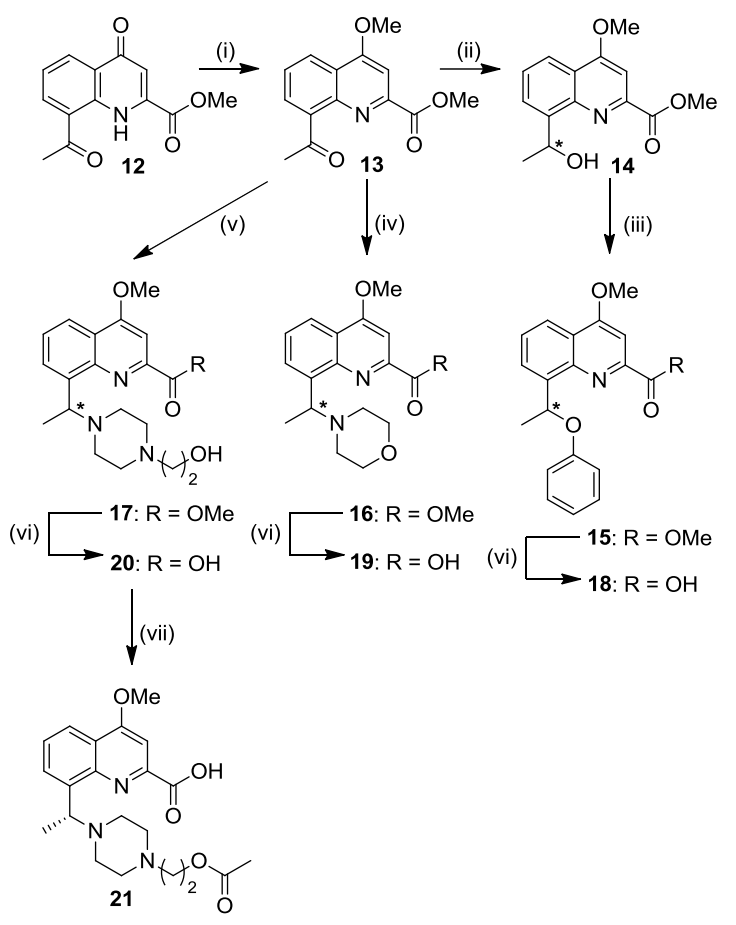

Scheme 2. Synthesis of chiral quinoline monomers. Reagents and conditions: (i) $\mathrm{Me}_{2} \mathrm{SO}_{4}, \mathrm{~K}_{2} \mathrm{CO}_{3}$, acetone, reflux, $1 \mathrm{~h}$; (ii) $\mathrm{NaBH}_{4}, \mathrm{C}_{2} \mathrm{H}_{4} \mathrm{Cl}_{2}$, $55^{\circ} \mathrm{C}, 8 \mathrm{~h}$; (iii) phenol, DBAD, $\mathrm{PPh}_{3}$, toluene, $80{ }^{\circ} \mathrm{C}, 3 \mathrm{~h}$; (iv) morpholine, $\mathrm{Na}(\mathrm{OAc})_{3} \mathrm{BH}, \quad \mathrm{C}_{2} \mathrm{H}_{4} \mathrm{Cl}_{2}, \quad 55{ }^{\circ} \mathrm{C}, 24 \mathrm{~h}$; (v) 2-(1-piperazinyl)ethanol, $\mathrm{Na}(\mathrm{CN}) \mathrm{BH}_{3}, \mathrm{AcOH}, \mathrm{C}_{2} \mathrm{H}_{4} \mathrm{Cl}_{2}, 55^{\circ} \mathrm{C}, 3 \mathrm{~h}$; (vi) $\mathrm{LiOH} . \mathrm{H}_{2} \mathrm{O}$, dioxane $/ \mathrm{H}_{2} \mathrm{O}, 1$ h; (vii) $\mathrm{Ac}_{2} \mathrm{O}$, DIEA, $\mathrm{CHCl}_{3}, 4 \mathrm{~h}$ (carried out on $\boldsymbol{R}-\mathbf{2 0}$ ).
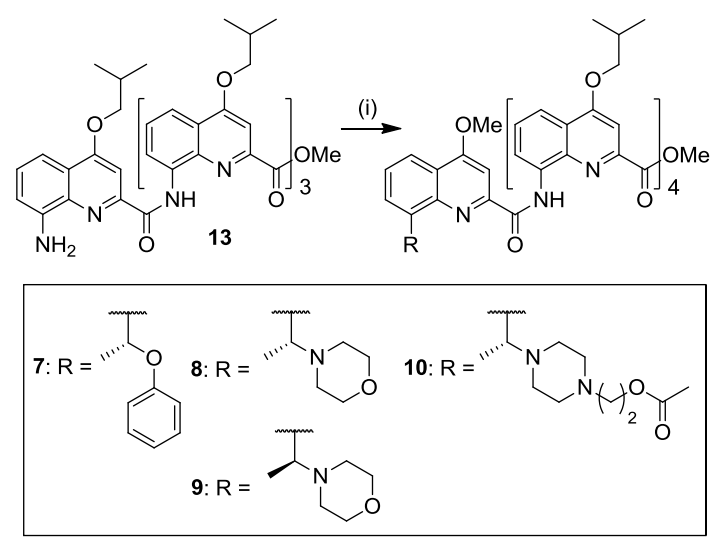

Scheme 3. Synthesis of pentamers bearing N-terminal handedness inducing groups from the tetramer amine precursor, 13. Reagents and conditions: (i) (a) Chiral monomer unit, 1-chloro- $N, N, 2$-trimethyl-1-propenylamine, $\mathrm{CH}_{2} \mathrm{Cl}_{2}, \mathrm{rt}, 1 \mathrm{~h}$; (b) Product from (a), $i \mathrm{Pr}_{2} \mathrm{EtN}, \mathrm{CHCl}_{3}$, rt, 20 h. (N.B. Configuration of $\mathbf{1 0}$ inferred from $\mathrm{CD}$ spectrum (i.e. the resulting induction of $M$-helix) and comparison between $\mathbf{Q}_{\text {Pip }}$ and $\mathbf{Q}_{\mathbf{M o r p h}} \mathrm{CD}$ spectra. See Supporting Information).

The remaining two designs incorporated either morpholine or piperazine via the amine functionality. While these would not be capable of stacking interactions with the aromatic foldamer backbone, they would be useful as solubilising groups. In addition, installation of a piperazine moiety might also allow further functionalization of the foldamer via the terminal amine group.

The starting quinolinone $\mathbf{1 2}$ was functionalised with a simple methoxy group in the 4-position to yield the common ketone precursor. This was then either reduced and subsequently treated with phenol under Mitsunobu conditions to yield the racemic QPhen monomer, or underwent direct reductive amination to incorporate the morpholine or piperazinylethanol moieties. Subsequent separation of each enantiomer from the racemic mixture by preparative chiral HPLC was followed by saponification yielding the free acids of the monomers. The terminal alcohol functionality of the QPip monomer was then acetylated before activation as the acid chloride, to avoid the possibility of side-reactions at this position. The configurations of both enantiomers of the QMorph monomer were confirmed by their crystal structures. The remaining monomers proved difficult to crystallize. Their configurations were therefore inferred from their CD sign at 300 $\mathrm{nm}$ by comparison with that of the QMorph enantiomers (see Supporting Information).

In order to assess handedness induction by means of QPip, QMorph, and $\mathbf{Q}_{\text {Phen, we initially designed a pentameric sequence }}$ with side-chain functionality compatible with a range of organic solvents. We have previously demonstrated that adjusting oligomer length and the solvents in which it was dissolved gave us an ability to 'tune' the rate of helix handedness inversion. ${ }^{[8,9]}$ In this case, a pentameric sequence in a non-polar solvent such as chloroform would possess slow enough handedness inversion kinetics on an NMR timescale that the separate diastereoisomers could be visualised as a distinct set of resonances. However, this behaviour would still be sufficiently fast that equilibration between handedness forms would be complete after minutes, and thus the degree of handedness induction could be accurately assessed. Quantitative induction could therefore be initially determined by analysis of the ${ }^{1} \mathrm{H}-\mathrm{NMR}$ spectrum, which should show a single set of resonances. Analysis by CD would then confirm the induction of a single helix handedness form, indicated by a deflection at the quinoline chromophore absorption region, discounting the possibility that separate diastereoisomers possessed exactly overlapping NMR resonances. 
The tetramer amine 13 (Scheme 3) was synthesised using the procedures previously reported by our group ${ }^{[21]}$ and functionalized with a terminal chiral building block via the acid chloride. It was found that the tertiary amine present on the $\mathbf{Q}_{\text {Morph }}$ and $\mathbf{Q}_{\text {Pip }}$ units could interfere with the activation. Prior protonation of these amines allowed the clean activation of acid functions into acid chlorides. No such problems were associated with the QPhen building block.

${ }^{1} \mathrm{H}-\mathrm{NMR}$ analysis of pentamer 7 indicated the presence of both $P$ and $M$ diastereoisomers in an almost 1:1 ratio, as demonstrated by the eight carboxamide resonances between 11 and $12 \mathrm{ppm}$ (Figure 6). This was confirmed by CD experiments (Figure 7) which showed negligible deflection at $390-410 \mathrm{~nm}$. In contrast, pentamers $\mathbf{8}$ and $\mathbf{9}$ possessing respectively the $R$ and $S$ enantiomers of the QMorph monomer were each found to afford an identical single set of ${ }^{1} \mathrm{H}-\mathrm{NMR}$ signals, indicating quantitative handedness induction. This was also observed in $d_{3}-\mathrm{MeCN} / \mathrm{CDCl}_{3}$ (3:1), $d_{3-}$ $\mathrm{MeOH}$ and in $d_{6}$-DMSO. Compound $\mathbf{8}$ was found to remain as one set of NMR signals in $d_{6}$-DMSO for over four weeks at room temperature, and even after heating to $50{ }^{\circ} \mathrm{C}$ for 24 hours.
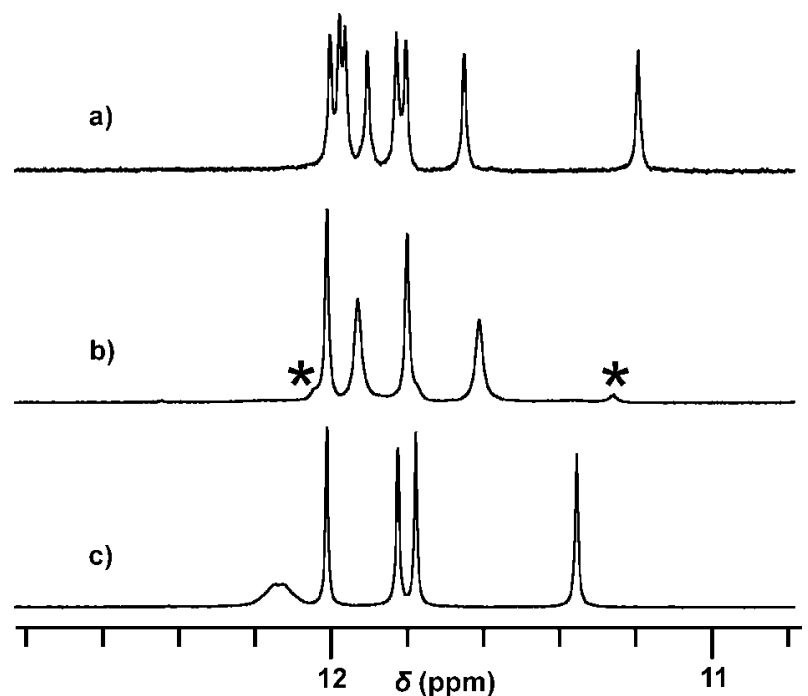

Figure 6. Carboxamide region of ${ }^{1} \mathrm{H}-\mathrm{NMR}$ spectra in $\mathrm{CDCl}_{3}$ for: (a) compound 7; (b) Unprotonated form of compound $\mathbf{8}$ * shows minor set of peaks); (b) Hydrochloride salt of compound $\mathbf{8}$.

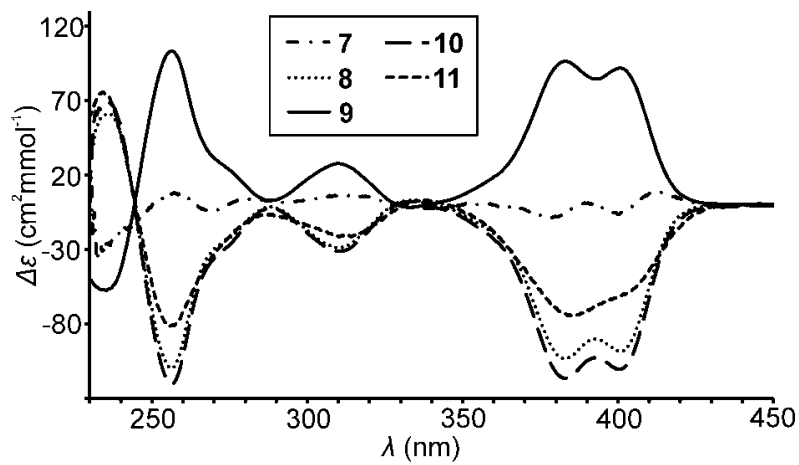

Figure 7. CD spectra of compounds $\mathbf{7 - 1 1}$, recorded using $50-60 \mu \mathrm{M}$ solutions.

Analysis by CD confirmed single helix handedness, with intense bands at 390-410 nm. Again, by analogy to previous work, the negative sign of these bands indicate a preferred $M$ handedness for compound $\mathbf{8}$, possessing the $(\boldsymbol{R})-\mathbf{Q}_{\text {Morph }}$ monomer, and the inverse for compound $\mathbf{9}$ (possessing the $(\boldsymbol{S})$-QMorph monomer) indicating a preferred $P$ handedness. Interestingly, the protonation state of the morpholine unit appeared to slightly enhance handedness induction efficiency- the ${ }^{1} \mathrm{H}-\mathrm{NMR}$ spectrum of the unprotonated form of $\mathbf{8}$ showed the presence of minor amide resonances (Figure 6), thought to be those of the unfavoured $P$ diastereoisomer, which were eliminated on conversion to the hydrochloride salt. CD experiments (See Supporting Information) supported this, showing a small reduction in intensity in the unprotonated form, perhaps indicating a slight decrease in induction efficiency.

The QPip monomer also demonstrated an ability to quantitatively induce helix handedness, with compound $\mathbf{1 0}$ showing a negative $\mathrm{CD}$ deflection of approximately the same magnitude as that of compound 8 at $390-410 \mathrm{~nm}$. This indicates the monomer is of the $R$-configuration and supports our earlier inference from comparison of the QPip CD spectra with those of QMorph. As with the morpholine functionalised monomer, the protonation state appeared to slightly affect induction efficiency (see Supporting Information).

In order to assess handedness induction efficiency in water, we returned to the solid phase synthesis methodology for the production of a simple pentameric sequence consisting of an $\mathrm{N}$ terminal $(\boldsymbol{R})-\mathbf{Q}$ Morph monomer plus four $\mathbf{Q}^{\text {Orn }}$ residues. Including the morpholine functionality, this sequence would be a pentacationic species after deprotection, and thus was anticipated to be highly water-soluble at neutral $\mathrm{pH}$ or below. In addition, this pentameric sequence would also possess handedness inversion kinetics fast enough in water to permit racemization, and thus assess handedness induction in this medium.

Low loading Wang bromide resin was prepared using the procedure of Morales and co-workers ${ }^{[22]}$ and functionalized with the first quinoline monomer in the presence of $\mathrm{Cs}_{2} \mathrm{CO}_{3}$.

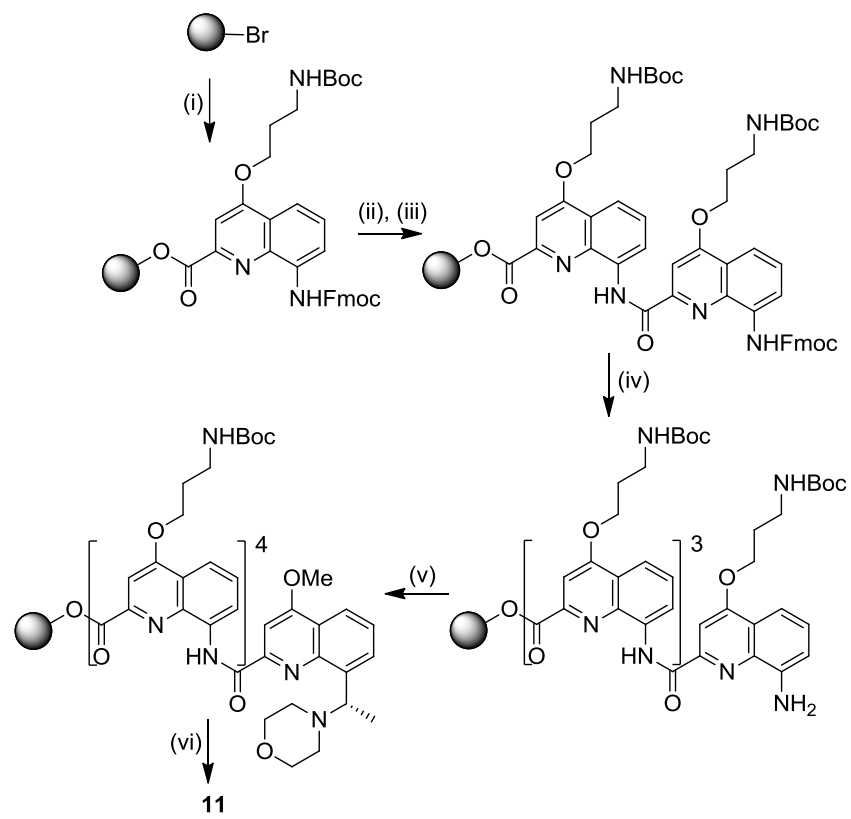

Scheme 4. SPS of water soluble pentamer with $\mathrm{N}$-terminal helix sense inducing group. Reagents and conditions: (i) $\mathrm{Fmoc}-\mathrm{O}^{\mathrm{Orn}(\mathrm{Boc})}-\mathrm{OH}, \mathrm{Cs}_{2} \mathrm{CO}_{3}$, $i \mathrm{Pr}_{2} \mathrm{EtN}$, DMF, microwave $50 \mathrm{~W}$, ramp to $50{ }^{\circ} \mathrm{C}$, hold $50{ }^{\circ} \mathrm{C}$ for $5 \mathrm{~min}$, repeat once; (ii) $20 \% v / v$ piperidine in DMF, rt, 10 min, repeat twice; (iii) (a) Fmoc-Q $\mathrm{Q}$ (rn(Boc)-OH, 1-chloro- $N, N, 2$-trimethyl-1-propenylamine, $\mathrm{CH}_{2} \mathrm{Cl}_{2}$, rt, $1 \mathrm{~h}$; (b) Product from (a), $i \mathrm{Pr}_{2} \mathrm{EtN}$, THF, microwave $50 \mathrm{~W}$, ramp to $50{ }^{\circ} \mathrm{C}$, hold $50{ }^{\circ} \mathrm{C}$ for $15 \mathrm{~min}$, repeat once; (iv) Repeat steps (ii)-(iii); (v) (a) (R)-Q $\mathbf{Q}_{\text {Morph }}$, 1-chloro- $N, N, 2$-trimethyl-1-propenylamine, $\mathrm{CH}_{2} \mathrm{Cl}_{2}, \mathrm{rt}, 1 \mathrm{~h}$; (b) Product from (a), $i \mathrm{Pr}_{2} \mathrm{EtN}, \mathrm{CHCl}_{3}$, microwave $50 \mathrm{~W}$, ramp to $50{ }^{\circ} \mathrm{C}$, hold $50{ }^{\circ} \mathrm{C}$ for $30 \mathrm{~min}$, then repeat at rt, $20 \mathrm{~h}$. 
The Fmoc group was deprotected and SPS continued using the methodology previously detailed in the literature (Scheme 4). Activation of the $(\boldsymbol{R})$-QMorph unit was preceded by protonation of its tertiary amine group, in order for efficient coupling to be carried out. The crude foldamer was removed from the resin with 50/48/2 $\mathrm{TFA} / \mathrm{CH}_{2} \mathrm{Cl}_{2} / i \mathrm{Pr}_{3} \mathrm{SiH} v / v / v$ and purified by RP-HPLC. ${ }^{1} \mathrm{H}-\mathrm{NMR}$ analysis in both $\mathrm{D}_{2} \mathrm{O}$ and $d_{6}$-DMSO revealed the presence of a single set of signals, indicating quantitative handedness induction, and this was confirmed by CD experiments which showed the expected negative deflection (Figure 7). Compound $\mathbf{1 1}$ was found to remain as one set of NMR signals in $\mathrm{D}_{2} \mathrm{O}$ even after heating at $40{ }^{\circ} \mathrm{C}$ for 48 hours.

\section{Conclusions}

Two methods for the isolation of separate $P$ and $M$ helices of quinoline oligoamides have been assessed. Incorporation of a phenylalanine residue at the C-terminus of two diverselyfunctionalized water-soluble octamers was in both cases found to afford a mixture of the $P$ and $M$ diastereoisomers with strikingly different retention times. RP-HPLC separation of the diastereoisomers was found to be straightforward, with each demonstrating a marked stability in water, indicating extremely slow kinetics of handedness inversion under these conditions, regardless of side chain composition, and even in the case of the multicationic species. The facility of this method and the availability of the $\mathrm{N}$-terminus for further functionalization make it attractive in instances where foldamer length (and therefore the resulting slow kinetics of handedness inversion) preclude the use of ICD to determine chirality-dependent interactions with biological targets such as protein surfaces.

Two chiral quinoline monomers were found to offer quantitative induction of helix handedness in both organic and aqueous conditions when installed at the $\mathrm{N}$-terminus of pentameric sequences. These units should provide solubility in a greater range of solvents than the camphanyl group, and due to their smaller steric bulk, may be less likely to disrupt potential foldamerbiomolecule interactions. In addition, the piperazine moiety provides the opportunity for further functionalization of the foldamer after the chiral unit, for example tethering fluorescent probes or small molecule enzyme inhibitors.

These methods for handedness control will serve not only to aid investigation into the chirality-dependence of foldamer-target interactions, but also to facilitate the isolation of discrete, stable handedness forms of a foldamer sequence for use in biological and biophysical assays.

\section{Experimental Section}

General Methods. Low loading Wang resin was purchased from Novabiochem. Ghosez reagent (1-chloro- $N, N, 2$-trimethyl-1propenylamine) was purchased from Sigma Aldrich. $\mathrm{N}, \mathrm{N}$ diisopropylethylamine was distilled over calcium hydride. Analytical grade organic solvents were used for solid phase synthesis. Anhydrous THF and $\mathrm{CHCl}_{2}$ for solution and solid phase synthesis were dispensed from an MBRAUN SPS-800 solvent purification system. RP-HPLC-quality acetonitrile and MilliQ water were used for RP-HPLC analyses and purification. Reactions requiring anhydrous conditions were performed under nitrogen. ${ }^{1} \mathrm{H}-\mathrm{NMR}$ spectra were measured at 300,400 or $500 \mathrm{MHz}$ and ${ }^{13} \mathrm{C}$ NMR spectra were measured at 75, 100 or $125 \mathrm{MHz}$. Chemical shifts are reported in $\mathrm{ppm}$ and are calibrated against residual solvent signals of $\mathrm{CDCl}_{3}(\delta 7.26,77.2), \mathrm{DMSO}_{-} \mathrm{d}_{6}(\delta 2.50,39.4)$, or $\mathrm{D}_{2} \mathrm{O}(\delta$ 4.79). All coupling constants are reported in hertz $(\mathrm{Hz})$. Signals were abbreviated as s, singlet; brs, broad singlet; d, doublet; t, triplet; q, quartet; m, multiplet, dd, doublet of doublets Silica gel chromatography was performed using Merck Kieselgel Si 60. Thin layer chromatography was performed using Merck Kieselgel Si 60 F254 plates. Chiral preparative HPLC was performed using a Daicel Chiralpak AD column with isocratic ethanol/heptane mixtures as the eluent running at either $100 \mathrm{~mL}$ $\min ^{-1}$ (QPhen synthesis) or $50 \mathrm{~mL} \min ^{-1}$ (QMorph and QPip syntheses). RP-HPLC analyses were performed at $1.5 \mathrm{~mL} \mathrm{~min}^{-1}$ using a Machery-Nagel Nucleodur C18 or C8 Gravity column (4.6 x $100 \mathrm{~mm}, 3 \mu \mathrm{m})$. The mobile phase was composed of $0.1 \%(v / v)$ TFA- $\mathrm{H}_{2} \mathrm{O}$ (Solvent A) and $0.1 \%$ TFA- $\mathrm{CH}_{3} \mathrm{CN}$ (Solvent B) running the following gradients: 5-30\% B over $13 \mathrm{~min}$, then $30-100 \% \mathrm{~B}$ over 5 min (System A), 5-100\% B over 13 min then $100 \%$ B for 5 min (System B), or $20-60 \%$ B over 25 min then $60-100 \%$ B for 5 min (System C). Monitoring by UV detection was carried out at $214 \mathrm{~nm}, 254 \mathrm{~nm}$ and $300 \mathrm{~nm}$ using a diode array detector. Semipreparative purifications of oligomers were performed at $4 \mathrm{~mL}$ $\min ^{-1}$ on a semipreparative HPLC using a Machery-Nagel Nucleodur C18 HTEC column $(21 \mathrm{~mm} \times 125 \mathrm{~mm}, 5 \mu \mathrm{m})$. The mobile phase was the same as for the analytic system, running the following gradients: 5-26\% B over 40 minutes (System D), 5-40\% B over 20 minutes (System E) or $20-55 \%$ B over 35 minutes (System F). Monitoring by UV detection was carried out at $254 \mathrm{~nm}$ and $300 \mathrm{~nm}$ using a diode array detector. High resolution electrospray ionization time of flight (ESI-TOF) mass spectra were measured in the positive ion mode on a Waters/Micromass Q-Tof Ultima. X-ray diffraction experiments were carried out on a high flux RIGAKU FRX rotating anode at the $\mathrm{Cu} \mathrm{K} \alpha$ wavelength.

Monomer synthesis. Fmoc- $Q^{\text {Hyd }}$, Fmoc- $Q^{\text {Ala }}$, Fmoc- $Q^{\text {Leu }}$, Fmoc$\mathrm{Q}^{\mathrm{Asp}}$ and Fmoc-Q $\mathrm{Q}^{\text {Orn }}$ were synthesized using the methods previously reported. ${ }^{[4,17]}$ Fmoc- $\mathrm{Q}^{\mathrm{TEG}}$ was provided by the Servier Research Institute of Medicinal Chemistry, Hungary.

Methyl 8-acetyl-4-methoxy-quinoline-2-carboxylate 13. 491 $\mathrm{mg}$ of methyl 8-acetyl-4-hydroxy-quinoline-2-carboxylate ${ }^{[20]}(2.00$ $\mathrm{mmol}$ ) was dissolved in $10 \mathrm{~mL}$ acetone, then $553 \mathrm{mg}$ potassium carbonate $(4.00 \mathrm{mmol})$ and $182 \mu \mathrm{L}$ dimethyl sulfate $(2.00 \mathrm{mmol})$ were added. The mixture was stirred at reflux for 1 hour, then cooled to rt. Water was added and the resulting precipitate was filtered, washed with water to afford the title compound as a white solid (424 mg, 82\%). ${ }^{1} \mathrm{H}-\mathrm{NMR}$ (400 MHz, DMSO-d 6 ): $\delta=8.30$ $(\mathrm{dd}, 1 \mathrm{H}, J=8.3,1.5), 7.93$ (dd, $1 \mathrm{H}, J=7.1,1.5), 7.73$ (dd, $1 \mathrm{H}, J=$ 8.3, 7.1), 7.57 (s, 1H), 4.13 (s, 3H), 3.96 (s, 3H), $2.88(\mathrm{~s}, 3 \mathrm{H}) .{ }^{13} \mathrm{C}$ NMR (100 MHz, DMSO-d $\left.{ }_{6}\right): \delta=202.9,165.6,163.5,149.3$, $145.2,139.9,130.6,127.9,125.2,121.8,101.1,57.1,53.4,33.2$. HRMS calculated for $\mathrm{C}_{14} \mathrm{H}_{13} \mathrm{NO}_{4}$ : 259.0845; found 260.0916, [M + $\mathrm{H}]^{+}$.

Methyl 8-(1-hydroxyethyl)-4-methoxy-quinoline-2carboxylate 14. $7.519 \mathrm{~g}$ of methyl 8-acetyl-4-methoxy-quinoline2-carboxylate $(29.00 \mathrm{mmol})$ was dissolved in $200 \mathrm{~mL}$ dry 1,2 dichloroethane, then $3.292 \mathrm{~g}$ sodium borohydride $(87.00 \mathrm{mmol})$ was added. The mixture was stirred at $55{ }^{\circ} \mathrm{C}$ for 8 hours, then cooled to rt. The mixture was diluted with $100 \mathrm{~mL}$ methylene chloride, and acetic acid was added to quench. The mixture was then washed with water and brine and extracted with $\mathrm{CH}_{2} \mathrm{Cl}_{2}$. The combined organic layer was dried over $\mathrm{Na}_{2} \mathrm{SO}_{4}$, filtered and concentrated under reduced pressure. The crude product was purified via silica gel chromatography (heptane/EtOAc) to afford the title compound as a white solid $(5.096 \mathrm{~g}, 67 \%) .{ }^{1} \mathrm{H}-\mathrm{NMR}(500$ MHz, DMSO-d 6 ): $\delta=8.07$ (dd, $1 \mathrm{H}, J=8.3,1.4), 7.94(\mathrm{~d}, 1 \mathrm{H}, J=$ 7.0), $7.68(\mathrm{dd}, 1 \mathrm{H}, J=8.1,7.3,7.55(\mathrm{~s}, 1 \mathrm{H}), 5.84(\mathrm{~m}, 1 \mathrm{H}), 5.36(\mathrm{~d}$, $1 \mathrm{H}, J=4.7), 4.12(\mathrm{~s}, 3 \mathrm{H}), 3.96(\mathrm{~s}, 3 \mathrm{H}), 1.45(\mathrm{~d}, 3 \mathrm{H}, J=6.4) .{ }^{13} \mathrm{C}-$ NMR $(125 \mathrm{MHz}$, DMSO-d 6$): \delta=166.0,163.4,148.4,146.5$, $145.1,128.2,126.9,121.6,120.2,100.5,64.5,56.9,53.3,26.2$ HRMS calculated for $\mathrm{C}_{14} \mathrm{H}_{15} \mathrm{NO}_{4}$ : 261.1001; found 262.1072, [M + $\mathrm{H}]^{+}$. 
$1 R$ and $1 S$ methyl 4-methoxy-8-[1-phenoxyethyl]quinoline-2carboxylate 15. $4.734 \mathrm{~g}$ of methyl 8-(1-hydroxyethyl)-4-methoxyquinoline-2-carboxylate (18.12 $\mathrm{mmol}), 2.555 \mathrm{~g}$ phenol (27.15 $\mathrm{mmol})$ and $8.335 \mathrm{~g}$ ditertbutylazodicarboxylate $(36.20 \mathrm{mmol})$ were dissolved in $400 \mathrm{~mL}$ dry toluene, then $12.067 \mathrm{~g}$ of polymer-bound triphenylphosphine $(36.20 \mathrm{mmol}, 3 \mathrm{mmol} / \mathrm{g}$ ) was added and the mixture was stirred at $80{ }^{\circ} \mathrm{C}$ under nitrogen atmosphere for 3 hours. It was then filtered, washed with ethyl acetate and the filtrate was concentrated under reduced pressure. The crude product was purified via silica gel chromatography (heptane/EtOAc) to afford racemic methyl 4-methoxy-8-[1phenoxyethyl]quinoline-2-carboxylate $(3.388 \mathrm{~g}, \quad 55 \%)$. The enantiomers were then separated by chiral chromatography (ethanol/heptane 15:85) to obtain each enantiomer in ee $\geq 99.8 \%$. The absolute configuration of the enantiomers was not determined, however comparison of the CD spectrum of the QPhen monomer precursors with those of the QMorph monomers (See Supporting Information) indicated that the first eluting enantiomer was 4methoxy-8-[(1S)-1-phenoxyethyl]quinoline-2-carboxylate and the second eluting enantiomer was 4-methoxy-8-[(1R)-1phenoxyethyl]quinoline-2-carboxylate. ${ }^{1} \mathrm{H}-\mathrm{NMR} \quad(400 \mathrm{MHz}$, DMSO-d $\left.{ }_{6}\right): \delta=8.11(\mathrm{dd}, 1 \mathrm{H}, J=8.3,1.4), 7.83(\mathrm{dd}, 1 \mathrm{H}, J=7.2$, $1.2), 7.65(\mathrm{dd}, 1 \mathrm{H}, J=8.3,7.3), 7.62(\mathrm{~s}, 1 \mathrm{H}), 7.14(\mathrm{~m}, 2 \mathrm{H}), 6.84-$ $6.78(\mathrm{~m}, 3 \mathrm{H}), 6.61(\mathrm{q}, 1 \mathrm{H}, J=6.3), 4.14(\mathrm{~s}, 3 \mathrm{H}), 3.99(\mathrm{~s}, 3 \mathrm{H}), 1.68$ $(\mathrm{d}, 3 \mathrm{H}, J=6.3) .{ }^{13} \mathrm{C}-\mathrm{NMR}\left(100 \mathrm{MHz}, \mathrm{DMSO}-\mathrm{d}_{6}\right): \delta=165.5$, $163.1,157.4,148.5,144.6,141.4,129.5,127.9,126.7,121.3$, $120.8,120.5,115.3,100.6,70.0,56.5,52.9$, 23.6. HRMS calculated for $\mathrm{C}_{20} \mathrm{H}_{19} \mathrm{NO}_{4}$ : 337.1314 ; found $338.1389,[\mathrm{M}+\mathrm{H}]^{+}$for first eluting enantiomer and $338.1396[\mathrm{M}+\mathrm{H}]^{+}$for second eluting enantiomer.

$1 R$ and $1 S$ methyl 4-methoxy-8-(1morpholinoethyl)quinoline-2-carboxylate 16. $1.919 \mathrm{~g}$ of methyl 8-acetyl-4-methoxy-quinoline-2-carboxylate $(7.40 \mathrm{mmol})$ was dissolved in $110 \mathrm{~mL}$ dry 1,2-dichloroethane, then $3.87 \mathrm{~mL}$ morpholine $(44.40 \mathrm{mmol})$ and $4.705 \mathrm{~g}$ sodium triacetoxyborohydride $(22.20 \mathrm{mmol})$ were added and the mixture was stirred at $55{ }^{\circ} \mathrm{C}$ for 24 hours. It was then diluted with $150 \mathrm{~mL}$ water and extracted with $\mathrm{CH}_{2} \mathrm{Cl}_{2}$. The combined organic layer was dried over $\mathrm{Na}_{2} \mathrm{SO}_{4}$, filtered and concentrated under reduced pressure. The crude product was purified via silica gel chromatography (heptane/EtOAc) to afford racemic methyl 4methoxy-8-(1-morpholinoethyl)quinoline-2-carboxylate $(1.847 \mathrm{~g}$, $76 \%)$. The enantiomers were then separated by chiral chromatography (ethanol/heptane 15:85 with $0.05 \% \mathrm{v} / \mathrm{v}$ diethylamine). The first eluting enantiomer was determined by $\mathrm{X}$ ray diffraction (See Supporting Information) as methyl 4-methoxy8-[(1S)-1-morpholinoethyl]quinoline-2-carboxylate (CCDC 990871), and the second eluting enantiomer was determined also by X-ray diffraction (See Supporting Information) as methyl 4methoxy-8-[(1R)-1-morpholinoethyl]quinoline-2-carboxylate

(CCDC 990870). ${ }^{1} \mathrm{H}-\mathrm{NMR}$ (500 MHz, DMSO-d6): $\delta=8.10(\mathrm{dd}$, $1 \mathrm{H}, J=8.3,1.4), 7.93(\mathrm{dd}, 1 \mathrm{H}, J=7.2,1.3), 7.70(\mathrm{dd}, 1 \mathrm{H}, J=8.1$, $7.5), 7.55(\mathrm{~s}, 1 \mathrm{H}), 4.95(\mathrm{q}, 1 \mathrm{H}, J=6.8), 4.12(\mathrm{~s}, 3 \mathrm{H}), 3.96(\mathrm{~s}, 3 \mathrm{H})$, $3.56(\mathrm{~m}, 4 \mathrm{H}), 2.48(\mathrm{~m}, 2 \mathrm{H}), 2.29(\mathrm{~m}, 2 \mathrm{H}), 1.33(\mathrm{~d}, 3 \mathrm{H}, J=6.8)$. ${ }^{13} \mathrm{C}-\mathrm{NMR}\left(125 \mathrm{MHz}, \mathrm{DMSO}-\mathrm{d}_{6}\right): \delta=166.1,163.4,148.4,146.3$, $143.0,128.6,128.1,121.8,120.3,100.5,67.0,56.9,56.8,53.3$, 51.4, 20.5. HRMS (of racemate) calculated for $\mathrm{C}_{18} \mathrm{H}_{22} \mathrm{~N}_{2} \mathrm{O}_{4}$ : 330.1580; found 331.1639, $[\mathrm{M}+\mathrm{H}]^{+}$.

$1 R$ and $1 S$ methyl 8-(1-(4-(2-hydroxyethyl)piperazin-1yl)ethyl)-4-methoxy-quinoline-2-carboxylate 17. $3.370 \mathrm{~g}$ of methyl 8-acetyl-4-methoxy-quinoline-2-carboxylate $(13.00 \mathrm{mmol})$ was dissolved in $200 \mathrm{~mL}$ anhydrous 1,2-dichloroethane, then 14.36 $\mathrm{mL}$ 2-(1-piperazinyl)ethanol $(117.00 \mathrm{mmol}), 2 \mathrm{~mL}$ glacial acetic acid $(35 \mathrm{mmol})$ and $2.042 \mathrm{~g}$ sodium cyanoborohydride $(32.50$ mmol) were added to the solution. The mixture was stirred at $55{ }^{\circ} \mathrm{C}$ for 3 hours, then diluted with $200 \mathrm{~mL}$ saturated $\mathrm{NaCl}$ and extracted with $\mathrm{CH}_{2} \mathrm{Cl}_{2}$. The combined organic layer was dried over $\mathrm{Na}_{2} \mathrm{SO}_{4}$, filtered and concentrated under reduced pressure. The crude product was purified via silica gel chromatography, $\left(\mathrm{CH}_{2} \mathrm{Cl}_{2} / \mathrm{MeOH}\right)$ to afford racemic methyl 8-(1-(4- $(2-$ hydroxyethyl)piperazin-1-yl)ethyl)-4-methoxy-quinoline-2-

carboxylate $(2.631 \mathrm{~g}, 54 \%)$. The enantiomers were separated by chiral chromatography (ethanol/heptane 15:85 with $0.05 \% \mathrm{v} / \mathrm{v}$ diethylamine) to obtain the first eluting enantiomer in ee $=99.8 \%$ and the second eluting enantiomer in ee $=94.4 \%$. The absolute configuration of the enantiomers was not determined, however comparison of the CD spectrum of the QPip monomer precursors with those of the QMorph monomers (See Supporting Information) indicated that the first eluting enantiomer was methyl 8-[(1R)-1-(4(2-hydroxyethyl)piperazin-1-yl)ethyl]-4-methoxy-quinoline-2-

carboxylate and the second eluting enantiomer was methyl 8-[(1S)1-(4-(2-hydroxyethyl)piperazin-1-yl)ethyl]-4-methoxy-quinoline-

2-carboxylate. ${ }^{1} \mathrm{H}-\mathrm{NMR}\left(400 \mathrm{MHz}, \mathrm{DMSO}-\mathrm{d}_{6}\right): \delta=8.08(\mathrm{dd}, 1 \mathrm{H}$, $J=8.3,1.4), 7.91(\mathrm{dd}, 1 \mathrm{H}, J=7.2,1.4), 7.69(\mathrm{dd}, 1 \mathrm{H}, J=8.2$, $7.4), 7.55(\mathrm{~s}, 1 \mathrm{H}), 4.95(\mathrm{q}, 1 \mathrm{H}, J=6.7), 4.31(\mathrm{t}, 1 \mathrm{H}, J=5.4), 4.12$ (s, 3H), 3.96 (s, 3H), $3.42(\mathrm{~m}, 2 \mathrm{H}), 2.38$ (br s, 4H), $2.32(\mathrm{~m}, 2 \mathrm{H})$, 2.30 (br s, $4 \mathrm{H}), 1.33$ (d, 3H, $J=6.7) .{ }^{13} \mathrm{C}-\mathrm{NMR}(100 \mathrm{MHz}, \mathrm{DMSO}-$ $\left.\mathrm{d}_{6}\right): \delta=166.1,163.4,148.3,146.3,143.4,128.5,128.1,121.8$, 120.2, 100.4, 60.8, 58.9, 56.9, 56.4, 55.4, 54.1, 53.3, 50.6, 20.8. HRMS calculated for $\mathrm{C}_{20} \mathrm{H}_{27} \mathrm{~N}_{3} \mathrm{O}_{4}: 373.2002$; found $374.2064[\mathrm{M}+$ $\mathrm{H}]^{+}$for first eluting enantiomer and $374.2053[\mathrm{M}+\mathrm{H}]^{+}$for second eluting enantiomer.

General method for $Q_{Y}$ monomer precursor saponification. The corresponding ester was dissolved in dioxane-water 5:1 (10 $\mathrm{mL} / \mathrm{mmol}$ ) and 3 eq. lithium hydroxide monohydrate was added. The mixture was stirred at $\mathrm{rt}$ until no further conversion was observed by TLC. The mixture was then neutralized with $1.25 \mathrm{M}$ $\mathrm{HCl}$ in ethanol (3 equiv) and concentrated under reduced pressure. The crude product was purified via preparative reversed phase chromatography using an Armen Spot Liquid Chromatography system with a Gemini-NX ${ }^{\circledR} 10 \mu \mathrm{M} \mathrm{C} 18,250 \mathrm{~mm} \times 50 \mathrm{~mm}$ i.d. column from Phenomenex, running at a flow rate of $118 \mathrm{~mL} \mathrm{~min}^{-1}$ with UV diode array detection $(210-400 \mathrm{~nm})$ using $5 \mathrm{mM}$ aqueous ammonium formate solution and acetonitrile or water and acetonitrile as eluents.

$\boldsymbol{R} / \boldsymbol{S}$-QPhen 18. ${ }^{1} \mathrm{H}-\mathrm{NMR}\left(500 \mathrm{MHz}, \mathrm{DMSO}-\mathrm{d}_{6}\right): \delta=13.33$ (br s, $1 \mathrm{H}), 8.10(\mathrm{dd}, 1 \mathrm{H}, J=8.3,1.5), 7.73(\mathrm{dd}, 1 \mathrm{H}, J=7.2,1.2), 7.63$ (dd, $1 \mathrm{H}, J=8.3,7.2), 7.63(\mathrm{~s}, 1 \mathrm{H}), 7.14(\mathrm{~m}, 2 \mathrm{H}), 6.86(\mathrm{~m}, 2 \mathrm{H})$, $6.80(\mathrm{~m}, 1 \mathrm{H}), 6.77(\mathrm{q}, 1 \mathrm{H}, J=6.3), 4.13(\mathrm{~s}, 3 \mathrm{H}), 1.65(\mathrm{~d}, 3 \mathrm{H}, J=$ 6.3). ${ }^{13} \mathrm{C}$ NMR (125 MHz, DMSO- $\left.\mathrm{d}_{6}\right): \delta=166.3,163.2,157.4$, $149.1,144.4,141.6,129.4,127.8,126.6,121.3,120.7,120.4$ 115.3, 100.2, 70.0, 56.5, 23.7. HRMS calculated for $\mathrm{C}_{19} \mathrm{H}_{17} \mathrm{NO}_{4}$ : 323.1158; found $324.1229[\mathrm{M}+\mathrm{H}]^{+}$and $324.1228[\mathrm{M}+\mathrm{H}]^{+}$.

$\boldsymbol{R} / \boldsymbol{S}$-QMorph 19. ${ }^{1} \mathrm{H}-\mathrm{NMR}\left(500 \mathrm{MHz}, \mathrm{DMSO}-\mathrm{d}_{6}\right): \delta=8.11(\mathrm{dd}$, $1 \mathrm{H}, J=8.4,1.4), 7.92(\mathrm{dd}, 1 \mathrm{H}, J=7.2,1.3), 7.70$ (dd, $1 \mathrm{H}, J=8.3$, 7.3), 7.59 (s, 1H), 4.91 (q, 1H, $J=6.7), 4.15(\mathrm{~s}, 3 \mathrm{H}), 3.61(\mathrm{~m}, 4 \mathrm{H})$, $2.55(\mathrm{~m}, 2 \mathrm{H}), 2.35(\mathrm{~m}, 2 \mathrm{H}), 1.36(\mathrm{~d}, 3 \mathrm{H}, J=6.7) .{ }^{13} \mathrm{C}-\mathrm{NMR}(125$ MHz, DMSO-d6): $\delta=165.4,163.9,149.9,144.2,140.7,128.9$, $127.5,121.2,120.2,100.0,66.2,57.5,56.7,50.7,19.5$. HRMS calculated for $\mathrm{C}_{17} \mathrm{H}_{20} \mathrm{~N}_{2} \mathrm{O}_{4}$ : 316.1423 ; found $317.1502[\mathrm{M}+\mathrm{H}]^{+}$ (S-QMorph) and $317.1506[\mathrm{M}+\mathrm{H}]^{+}\left(\boldsymbol{R}-\mathbf{Q}_{\mathbf{M o r p h}}\right)$.

$1 R$ and $1 S$ 8-(1-(4-(2-hydroxyethyl)piperazin-1-yl)ethyl)-4methoxy-quinoline-2-carboxylic acid 20. ${ }^{1} \mathrm{H}-\mathrm{NMR}(500 \mathrm{MHz}$ DMSO- $_{6}$ ): 8.09 (dd, $\left.1 \mathrm{H}, J=8.3,1.4\right), 7.88(\mathrm{dd}, 1 \mathrm{H}, J=7.3,1.3$ ), $7.66(\mathrm{dd}, 1 \mathrm{H}, J=8.2,7.3), 7.56(\mathrm{~s}, 1 \mathrm{H}), 4.94(\mathrm{q}, 1 \mathrm{H}, J=6.7), 4.12$ $(\mathrm{s}, 3 \mathrm{H}), 3.48(\mathrm{t}, 2 \mathrm{H}, J=6.2), 2.58($ br s, $4 \mathrm{H}), 2.49-2.23(\mathrm{~m}, 6 \mathrm{H})$ 1.38 (d, 3H, $J=6.7) .{ }^{13} \mathrm{C}-\mathrm{NMR}\left(125 \mathrm{MHz}, \mathrm{DMSO}-\mathrm{d}_{6}\right): \delta=166.2$ $163.5,151.9,144.4,140.3,128.5,127.0,121.0,120.2,100.0,59.8$, 58.0, 57.5, 56.5, 52.8, 49.4, 19.6. HRMS calculated for $\mathrm{C}_{19} \mathrm{H}_{25} \mathrm{~N}_{3} \mathrm{O}_{4}: 359.1845$; found $360.1931[\mathrm{M}+\mathrm{H}]^{+}$and 360.1937 $[\mathrm{M}+\mathrm{H}]^{+}$. 
R-QPip 21. $300 \mathrm{mg}$ of 8-((1R)-1-(4-(2-hydroxyethyl)piperazin-1yl)ethyl)-4-methoxy-quinoline-2-carboxylic acid was dissolved in $\mathrm{CHCl}_{3}$ and stirred at $\mathrm{rt}$ under $\mathrm{N}_{2} .0 .872 \mathrm{~mL} i \operatorname{Pr}_{2} \mathrm{EtN}(5.00 \mathrm{mmol}, 6$ equiv) was then added, followed by $0.237 \mathrm{~mL} \mathrm{Ac} 2 \mathrm{O}(2.50 \mathrm{mmol}, 3$ equiv) and the mixture stirred at $\mathrm{rt}$ for $4 \mathrm{~h}$ under $\mathrm{N}_{2}$. Solvents were evaporated under reduced pressure, the crude residue dissolved in $6.0 \mathrm{~mL} \mathrm{THF} / \mathrm{H}_{2} \mathrm{O}(1: 1)$ and stirred for $3 \mathrm{~h}$ at $\mathrm{rt} .1 \mathrm{M} \mathrm{HCl}$ was then added dropwise to bring the mixture to $\mathrm{pH} 2$ and solvents evaporated under reduced pressure. The crude residue was purified by silica gel chromatography $\left(100 \% \mathrm{CH}_{2} \mathrm{Cl}_{2}\right.$ to $\mathrm{CH}_{2} \mathrm{Cl}_{2} / \mathrm{MeOH}$ $85: 5$ ) to yield the title compound as a white foam (225 $\mathrm{mg}, 67 \%)$. ${ }^{1} \mathrm{H}-\mathrm{NMR}\left(300 \mathrm{MHz}, \mathrm{CDCl}_{3}\right): \delta=8.30(\mathrm{dd}, 1 \mathrm{H}, J=8.4,1.3), 7.99$ (s, 1H), $7.80(\mathrm{~m}, 1 \mathrm{H}), 7.70(\mathrm{dd}, 1 \mathrm{H}, J=8.3,7.4), 4.32(\mathrm{~s}, 3 \mathrm{H}), 4.29$ $(\mathrm{m}, 1 \mathrm{H}), 4.21(\mathrm{t}, 2 \mathrm{H}, J=5.8), 2.94-2.84(\mathrm{~m}, 6 \mathrm{H}), 2.76(\mathrm{~m}, 2 \mathrm{H})$, $2.70(\mathrm{~m}, 2 \mathrm{H}), 2.07$ (s, 3H), $1.61(\mathrm{~d}, 3 \mathrm{H}, J=6.8) .{ }^{13} \mathrm{C}-\mathrm{NMR}(75$ MHz, DMSO-d6): $\delta=171.0,168.4,153.0,138.1,134.1,132.2$, 128.0, 122.5, 101.2, 64.0, 61.7, 57.8, 56.2, 52.2, 21.0, 18.2. HRMS calculated for $\mathrm{C}_{21} \mathrm{H}_{27} \mathrm{~N}_{3} \mathrm{O}_{5}$ : 401.1951; found $402.2041[\mathrm{M}+\mathrm{H}]^{+}$

Compound 4. Synthesized on a $0.022 \mathrm{mmol}(50 \mathrm{mg}$ Wang resin loading $0.44 \mathrm{mmolg}^{-1}$ ) scale, using the general methods previously reported ${ }^{[18]}$ The crude mixture of diastereoisomers was purified by RP-HPLC (System D) to yield each pure diastereoisomer as a yellow solid. P-4: (corresponding to first analytical peak, $5.0 \mathrm{mg}$, $21 \%)$. RP-HPLC (C18, System A) $\mathrm{R}_{\mathrm{t}}=9.83 \mathrm{~min} .{ }^{1} \mathrm{H}-\mathrm{NMR}(300$ MHz, DMSO-d $\left.\mathrm{d}_{6}\right): \delta=11.51(\mathrm{~s}, 1 \mathrm{H}), 11.30(\mathrm{~s}, 1 \mathrm{H}), 11.08(\mathrm{~s}, 1 \mathrm{H})$, $10.99(\mathrm{~s}, 1 \mathrm{H}), 10.94(\mathrm{~s}, 1 \mathrm{H}), 10.87(\mathrm{~s}, 1 \mathrm{H}), 8.49(\mathrm{~s}, 1 \mathrm{H}), 7.95-8.29$ (m, CHAr), 7.34-7.89 (m, 13H), 7.08-7.23 (m, 3H), 6.99 (s, 1H), $6.87(\mathrm{~s}, 1 \mathrm{H}), 6.78(\mathrm{~m}, 1 \mathrm{H}), 6.46-6.65(\mathrm{~m}, 9 \mathrm{H}), 6.34(\mathrm{~s}, 1 \mathrm{H}), 6.25$ $(\mathrm{m}, 2 \mathrm{H}), 5.97(\mathrm{~s}, 1 \mathrm{H}), 3.78-4.49(\mathrm{~m}, 16 \mathrm{H}), 3.03-3.17(\mathrm{~m}, 16 \mathrm{H})$. HRMS calculated for $\mathrm{C}_{115} \mathrm{H}_{117} \mathrm{~N}_{25} \mathrm{O}_{19}$ : 2151.8958; found $2152.9098[\mathrm{M}+\mathrm{H}]^{+}$. M-4: (corresponding to second analytical peak, $4.5 \mathrm{mg}$, 19\%). RP-HPLC (C18, System A): $\mathrm{R}_{\mathrm{t}}=10.11 \mathrm{~min}$. ${ }^{1} \mathrm{H}-\mathrm{NMR}(300 \mathrm{MHz}$, DMSO-d 6$): \delta=11.27(\mathrm{~s}, 1 \mathrm{H}), 11.14(\mathrm{~s}, 1 \mathrm{H})$, $11.06(\mathrm{~s}, 1 \mathrm{H}), 11.00(\mathrm{~s}, 1 \mathrm{H}), 10.90(\mathrm{~s}, 1 \mathrm{H}), 10.84(\mathrm{~s}, 1 \mathrm{H}), 8.47(\mathrm{~s}$, 1H), 7.96-8.22 (m, CHAr), 7.34-7.82 (m, 13H), 7.06-7.23 (m, $3 \mathrm{H}), 6.97(\mathrm{~s}, 1 \mathrm{H}), 6.86(\mathrm{~s}, 1 \mathrm{H}), 6.76(\mathrm{~m}, 3 \mathrm{H}), 6.51(\mathrm{~s}, 1 \mathrm{H}), 6.39(\mathrm{~m}$, $3 \mathrm{H}), 6.31(\mathrm{~s}, 1 \mathrm{H}), 6.20(\mathrm{~s}, 1 \mathrm{H}), 5.96(\mathrm{~s}, 1 \mathrm{H}), 4.07-4.46(\mathrm{~m}, 16 \mathrm{H})$, $3.11(\mathrm{~m}, 16 \mathrm{H}), 2.22(\mathrm{~m}, 16 \mathrm{H})$. HRMS calculated for $\mathrm{C}_{115} \mathrm{H}_{117} \mathrm{~N}_{25} \mathrm{O}_{19}$ : 2151.8958 ; found $2152.9098[\mathrm{M}+\mathrm{H}]^{+}$.

Compound 5. Synthesized on a $0.019 \mathrm{mmol}$ (50 mg Wang resin loading $0.38 \mathrm{mmolg}^{-1}$ ) scale, using the general methods previously reported ${ }^{[5,18]}$ The crude mixture of diastereoisomers was purified by RP-HPLC (System F) to yield each pure diastereoisomer as a pale yellow solid. $\boldsymbol{P} \mathbf{- 5}$ : (corresponding to first analytical peak) 2.2 mg (9\%). RP-HPLC (C18, System C) $\mathrm{R}_{\mathrm{t}}=14.37 \mathrm{~min} .{ }^{1} \mathrm{H}-\mathrm{NMR}$ (300 MHz, DMSO-d6): $\delta=11.61(\mathrm{~s}, 1 \mathrm{H}), 11.54(\mathrm{~s}, 1 \mathrm{H}), 11.44$ (s, $1 \mathrm{H}), 11.20(\mathrm{~s}, 1 \mathrm{H}), 11.02(\mathrm{~s}, 1 \mathrm{H}), 10.98(\mathrm{~s}, 1 \mathrm{H}), 10.87(\mathrm{~s}, 1 \mathrm{H})$, 10.77 (s, 1H), $9.14(\mathrm{t}, 1 \mathrm{H}, J=6.1), 8.13-7.33(\mathrm{~m}, 25 \mathrm{H}), 7.22-7.06$ $(\mathrm{m}, 4 \mathrm{H}), 6.93(\mathrm{~m}, 2 \mathrm{H}), 6.85-6.63(\mathrm{~m}, 6 \mathrm{H}), 6.46(\mathrm{~m}, 3 \mathrm{H}), 6.17(\mathrm{~m}$, $3 \mathrm{H}), 5.99$ (s, 1H), 5.95 (brs, 1H), 5.05-4.61 (m, 7H), $4.40(\mathrm{~m}, 2 \mathrm{H})$, 4.32-4.15 (m, 5H), $3.94(\mathrm{~m}, 3 \mathrm{H}), 3.68(\mathrm{~m}, 3 \mathrm{H}), 1.37-1.27(\mathrm{~m}, 8 \mathrm{H})$, 1.21-1.16 (m, 6H), $1.06(\mathrm{~m}, 4 \mathrm{H})$. HRMS calculated for $\mathrm{C}_{126} \mathrm{H}_{114} \mathrm{~N}_{22} \mathrm{O}_{27} \mathrm{~S}$ : 2398.7945; found $2398.7935[\mathrm{M}]^{+}$. M-5: (corresponding to second analytical peak) $2.8 \mathrm{mg}$ (11\%). RPHPLC (C18, System C) $\mathrm{R}_{\mathrm{t}}=14.53 \mathrm{~min} .{ }^{1} \mathrm{H}-\mathrm{NMR}(300 \mathrm{MHz}$, DMSO-d6): $\delta=11.58(\mathrm{~s}, 1 \mathrm{H}), 11.45(\mathrm{~s}, 1 \mathrm{H}), 11.16(\mathrm{~s}, 1 \mathrm{H}), 11.03$ $(\mathrm{s}, 1 \mathrm{H}), 10.99(\mathrm{~s}, 1 \mathrm{H}), 10.88(\mathrm{~s}, 1 \mathrm{H}), 10.80(\mathrm{~s}, 1 \mathrm{H}), 10.72(\mathrm{~s}, 1 \mathrm{H})$, $9.13(\mathrm{t}, 1 \mathrm{H}, J=5.9), 8.05-7.31(\mathrm{~m}, 27 \mathrm{H}), 7.20-7.05(\mathrm{~m}, 5 \mathrm{H}), 6.91$ $(\mathrm{s}, 1 \mathrm{H}), 6.84-6.62(\mathrm{~m}, 6 \mathrm{H}), 6.58(\mathrm{~s}, 1 \mathrm{H}), 6.55(\mathrm{~s}, 1 \mathrm{H}), 6.36(\mathrm{~m}, 3 \mathrm{H})$, 6.14 (s, 1H), $6.12(\mathrm{~s}, 1 \mathrm{H}), 5.99(\mathrm{~s}, 1 \mathrm{H}), 5.92$ (brs, 1H), 4.98-4.69 $(\mathrm{m}, 7 \mathrm{H}), 4.39(\mathrm{~m}, 2 \mathrm{H}), 4.23-4.11(\mathrm{~m}, 5 \mathrm{H}), 3.93(\mathrm{~m}, 3 \mathrm{H}), 3.65(\mathrm{~m}$, $3 \mathrm{H}), 1.35-1.26(\mathrm{~m}, 8 \mathrm{H}), 1.20-1.16(\mathrm{~m}, 6 \mathrm{H}), 1.05(\mathrm{~m}, 4 \mathrm{H}) . \mathrm{HRMS}$ calculated for $\mathrm{C}_{126} \mathrm{H}_{114} \mathrm{~N}_{22} \mathrm{O}_{27} \mathrm{~S}$ : 2398.7945 ; found $2398.7971[\mathrm{M}]^{+}$.

Compound 6. Synthesized on a $0.022 \mathrm{mmol}$ (50 mg Wang resin loading $\left.0.44 \mathrm{mmolg}^{-1}\right)$ scale, using the general methods previously reported ${ }^{[18]}$ to yield $55 \mathrm{mg}$ crude material (67\% crude yield) as a yellow solid. RP-HPLC (C8, System B): Major peaks at: $\mathrm{R}_{\mathrm{t}}=6.82$ min, $6.91 \mathrm{~min} .{ }^{1} \mathrm{H}-\mathrm{NMR}$ (300 MHz, DMSO-d 6 ): Approximate 1:1 ratio of diastereoisomers: $\delta=11.11(\mathrm{~s}, 1 \mathrm{H}), 10.93(\mathrm{~s}, 2 \mathrm{H}), 10.83(\mathrm{~s}$, $1 \mathrm{H}), 10.77(\mathrm{~s}, 2 \mathrm{H}), 10.73(\mathrm{~s}, 1 \mathrm{H}), 10.69(\mathrm{~s}, 1 \mathrm{H}), 10.25-10.41(\mathrm{~m}$, $10 \mathrm{H}), 9.93(\mathrm{~m}, 4 \mathrm{H}), 8.30(\mathrm{~s}, 2 \mathrm{H}), 7.67-6.60(\mathrm{~m}, 72 \mathrm{H}), 6.52(\mathrm{~s}, 1 \mathrm{H})$ $6.35(\mathrm{~m}, 13 \mathrm{H}), 4.82(\mathrm{~m},(9 \mathrm{H}), 4.63(\mathrm{~m}, 6 \mathrm{H}), 4.38(\mathrm{~m}, 5 \mathrm{H}), 3.97-$ 3.49 (m, 122H), 3.39-3.09 (m, 50H), 2.34-2.09 (m, 17H), $1.27(\mathrm{~m}$, 24H). ESI-MS calculated for $\mathrm{C}_{190} \mathrm{H}_{200} \mathrm{~N}_{28} \mathrm{O}_{45} \mathrm{~S}_{4}$ : 3721.31 ; found $1862.67[\mathrm{M}+2 \mathrm{H}]^{2+}, 1242.27[\mathrm{M}+3 \mathrm{H}]^{3+}$

Compound 7. $11.6 \mathrm{mg}(0.036 \mathrm{mmol})$ of QPhen was dissolved in $550 \mu \mathrm{L}$ anhydrous $\mathrm{CH}_{2} \mathrm{Cl}_{2}$ and stirred at $\mathrm{rt}$ under $\mathrm{N}_{2} .9 .5 \mu \mathrm{L}$ of 1 chloro- $N, N, 2$-trimethyl-1-propenylamine was added and the mixture stirred for $1 \mathrm{~h}$ at $\mathrm{rt}$, then evaporated to dryness on a vacuum manifold. $30 \mathrm{mg}$ of $\mathbf{1 3}^{[21]}(0.030 \mathrm{mmol})$ was dissolved in $230 \mu \mathrm{L}$ of anhydrous $\mathrm{CHCl}_{3}$, to which was added $12.6 \mu \mathrm{L}(0.072$ mmol) $i \operatorname{Pr} 2 \mathrm{EtN}$ and the mixture stirred at $0{ }^{\circ} \mathrm{C}$ under $\mathrm{N}_{2}$. The acid chloride was then added dropwise in $230 \mu \mathrm{L}$ anhydrous $\mathrm{CHCl}_{3}$ over approximately $5 \mathrm{~min}$, and the mixture stirred at $\mathrm{rt}$ for $15 \mathrm{~h}$. It was then diluted with $\mathrm{CHCl}_{3}$ and washed with a saturated solution of $\mathrm{NaHCO}_{3}, 0.1 \mathrm{M} \mathrm{HCl}, \mathrm{H}_{2} \mathrm{O}$ and brine, and the organic phase dried over $\mathrm{MgSO}_{4}$. The crude residue was then purified by silica gel chromatography (100\% cyclohexane to cyclohexane/EtOAc 7:3) to yield the title compound as a pale yellow solid $(28 \mathrm{mg}, 72 \%) .{ }^{1} \mathrm{H}-$ NMR $\left(300 \mathrm{MHz}, \mathrm{CDCl}_{3}\right)$ : Approximately 55:45 ratio of diastereoisomers: $\delta=11.97(\mathrm{~s}, 1 \mathrm{H}), 11.94(\mathrm{~s}, 1 \mathrm{H}), 11.93(\mathrm{~s}, 1 \mathrm{H})$, $11.87(\mathrm{~s}, 1 \mathrm{H}), 11.79(\mathrm{~s}, 1 \mathrm{H}), 11.77(\mathrm{~s}, 1 \mathrm{H}), 11.61(\mathrm{~s}, 1 \mathrm{H}), 11.16(\mathrm{~s}$ $1 \mathrm{H}), 8.72(\mathrm{~m}, 2 \mathrm{H}), 8.55(\mathrm{~m}, 2 \mathrm{H}), 8.27(\mathrm{~m}, 2 \mathrm{H}), 8.16(\mathrm{~m}, 1 \mathrm{H}), 8.08$ $(\mathrm{m}, 7 \mathrm{H}), 7.92(\mathrm{~m}, 1 \mathrm{H}), 7.81(\mathrm{~m}, 1 \mathrm{H}), 7.75-7.57(\mathrm{~m}, 5 \mathrm{H}), 7.53(\mathrm{~s}$, $1 \mathrm{H}), 7.48(\mathrm{~s}, 1 \mathrm{H}), 7.43-7.28(\mathrm{~m}, 5 \mathrm{H}), 7.03(\mathrm{~m}, 4 \mathrm{H}), 6.82(\mathrm{~m}, 4 \mathrm{H})$, $6.70(\mathrm{~m}, 2 \mathrm{H}), 6.57(\mathrm{~s}, 1 \mathrm{H}), 6.45-6.26(\mathrm{~m}, 7 \mathrm{H}), 6.14(\mathrm{t}, 1 \mathrm{H}, J=7.2)$, $5.75(\mathrm{~m}, 1 \mathrm{H}), 5.65(\mathrm{~m}, 1 \mathrm{H}), 4.49-3.38(\mathrm{~m}, 8 \mathrm{H}), 4.27(\mathrm{~m}, 2 \mathrm{H}), 3.95-$ $3.79(\mathrm{~m}, 10 \mathrm{H}), 3.70(\mathrm{~m}, 2 \mathrm{H}), 3.20(\mathrm{~s}, 3 \mathrm{H}), 3.15(\mathrm{~s}, 1 \mathrm{H}), 2.53(\mathrm{~m}$, $2 \mathrm{H}), 2.40-2.17(\mathrm{~m}, 6 \mathrm{H}), 1.43-1.11(\mathrm{~m}, 48 \mathrm{H}), 0.91(\mathrm{~d}, 3 \mathrm{H}, J=5.9)$, $0.34(\mathrm{~d}, 3 \mathrm{H}, J=6.4) .{ }^{13} \mathrm{C}-\mathrm{NMR}\left(75 \mathrm{MHz}, \mathrm{CDCl}_{3}\right): \delta=163.9$, $163.8,163.7,163.1,163.0,162.3,162.2,161.9,161.7,161.6$, $161.3,161.0,160.6,157.9,151.0,150.1,149.6,148.9,141.1$ $139.1,138.6,138.4,134.1,134.0,133.8,133.7,132.5,129.1$, $128.4,127.8,127.6,127.1,127.0,126.9,125.6,122.7,122.5$, $122.2,122.0,121.9,120.0,119.6,117.1,117.0,116.9,116.5$ 116.2, 115.8, 115.6, 114.8, 100.3, 99.6, 99.4, 98.7, 98.3, 97.8, 97.6, $97.2,75.6,75.4,75.2,75.0,74.9,70.0,68.7,56.2,52.1,28.4,28.3$, $28.2,28.1,26.9,21.4,19.5,19.4,19.3,16.8$. HRMS calculated for $\mathrm{C}_{76} \mathrm{H}_{75} \mathrm{~N}_{9} \mathrm{O}_{12}$ : 1305.5535 ; found $1306.5644[\mathrm{M}+\mathrm{H}]^{+}$.

General method for coupling of tertiary amine-based chiral monomer unit exemplified by compound $8.17 .5 \mathrm{mg}$ of $\boldsymbol{R}$-QMorph $(0.055 \mathrm{mmol})$ was suspended in $1 \mathrm{~mL}$ THF and $5.4 \mu \mathrm{L}$ of conc. $\mathrm{HCl}(0.055 \mathrm{mmol})$ was added. The mixture was stirred at $\mathrm{rt}$ for 20 min, then solvents evaporated under reduced pressure, coevaporating twice with toluene. The resulting hydrochloride salt was dissolved in $850 \mu \mathrm{L}$ anhydrous $\mathrm{CH}_{2} \mathrm{Cl}_{2}$ and stirred at $\mathrm{rt}$ under $\mathrm{N}_{2} .15 .0 \mu \mathrm{L}$ of chloro- $N, N, 2$-trimethyl-1-propenylamine was then added and the mixture stirred for $1 \mathrm{~h}$ at $\mathrm{rt}$, then evaporated to dryness on a vacuum manifold. $46 \mathrm{mg}$ of $\mathbf{1 3}^{[21]}(0.046 \mathrm{mmol})$ was dissolved in $350 \mu \mathrm{L}$ anhydrous $\mathrm{CHCl}_{3}$ to which was added $19.2 \mu \mathrm{L}$ $(0.110 \mathrm{mmol}) i \mathrm{Pr}_{2} \mathrm{EtN}$ and the mixture stirred at $0{ }^{\circ} \mathrm{C}$ under $\mathrm{N}_{2}$. The acid chloride was then added dropwise in $350 \mu \mathrm{L}$ anhydrous $\mathrm{CHCl}_{3}$ over approximately $5 \mathrm{~min}$, and the mixture stirred at $\mathrm{rt}$ for $15 \mathrm{~h}$. It was then diluted with $\mathrm{CHCl}_{3}$ and washed with a saturated solution of $\mathrm{NaHCO}_{3}, 0.1 \mathrm{M} \mathrm{HCl}, \mathrm{H}_{2} \mathrm{O}$ and brine, and the organic phase dried over $\mathrm{MgSO}_{4}$. The crude residue was then purified by silica gel chromatography $(100 \%$ cyclohexane to cyclohexane/EtOAc 7:3) to yield the title compound as a pale yellow solid (43 mg, 72\%). ${ }^{1} \mathrm{H}-\mathrm{NMR}\left(300 \mathrm{MHz}, \mathrm{CDCl}_{3}\right)$ : 12.10 (m, 1H), $11.98(\mathrm{~s}, 1 \mathrm{H}), 11.79(\mathrm{~s}, 1 \mathrm{H}), 11.74(\mathrm{~s}, 1 \mathrm{H}), 11.32(\mathrm{~s}, 1 \mathrm{H})$, 8.72 (dd, $1 \mathrm{H}, J=7.6,1.0), 8.47$ (dd, $1 \mathrm{H}, J=7.6,1.2), 8.34$ (dd, $1 \mathrm{H}, J=8.1,0.9), 8.18-7.91(\mathrm{~m}, 6 \mathrm{H}), 7.80-7.63(\mathrm{~m}, 3 \mathrm{H}), 7.52-7.35$ 
(m, 4H), $7.16(\mathrm{~m}, 3 \mathrm{H}), 6.94(\mathrm{~s}, 1 \mathrm{H}), 6.88(\mathrm{~s}, 1 \mathrm{H}), 6.59(\mathrm{~s}, 1 \mathrm{H}), 4.93$ $(\mathrm{m}, 1 \mathrm{H}), 4.44(\mathrm{~m}, 4 \mathrm{H}), 4.22(\mathrm{~m}, 1 \mathrm{H}), 4.06-3.92(\mathrm{~m}, 4 \mathrm{H}), 3.82(\mathrm{~m}$, $3 \mathrm{H}), 3.70(\mathrm{~m}, 1 \mathrm{H}), 3.49(\mathrm{~m}, 1 \mathrm{H}), 3.19(\mathrm{~m}, 5 \mathrm{H}), 2.53(\mathrm{~m}, 1 \mathrm{H}), 2.36$ $(\mathrm{m}, 7 \mathrm{H}), 1.92(\mathrm{~m}, 1 \mathrm{H}), 1.24(\mathrm{~m}, 24 \mathrm{H}), 0.35(\mathrm{~d}, 3 \mathrm{H}, J=6.8) .{ }^{13} \mathrm{C}-$ NMR $\left(75 \mathrm{MHz}, \mathrm{CDCl}_{3}\right): \delta=164.3,164.0,163.7,163.3,163.2$, $162.4,161.9,161.7,161.4,161.0,151.8,150.6,150.2,149.1$, $145.4,145.0,139.0,138.4,137.9,137.7,135.8,134.0,133.6$, $133.4,131.3,131.3,129.1,128.2,127.7,127.4,127.0,126.9$, $125.5,124.1,122.7,122.3,122.2,121.8,121.7,117.4,117.2$, 117.0, 116.9, 116.5, 116.1, 100.4, 99.8, 99.3, 98.2, 97.9, 75.7, 75.6, 75.4, 75.1, 63.2, 58.8, 56.6, 52.1, 51.3, 50.1, 34.3, 30.3, 28.4, 28.3, 28.2, 28.1, 19.5, 19.4, 19.3, 19.2, 14.8. HRMS calculated for $\mathrm{C}_{74} \mathrm{H}_{78} \mathrm{~N}_{10} \mathrm{O}_{12}: 1298.5801$; found $1299.5896[\mathrm{M}+\mathrm{H}]^{+}$.

Compound 9. Synthesised on a $0.042 \mathrm{mmol}$ scale using the general method described above to yield the title compound as a pale yellow solid (32 mg, 59\%). ${ }^{1} \mathrm{H}-\mathrm{NMR}\left(\mathrm{CDCl}_{3}\right)$ : $12.10(\mathrm{~m}, 1 \mathrm{H})$, 11.97 (s, 1H), 11.79 (s, 1H), $11.74(\mathrm{~s}, 1 \mathrm{H}), 11.32$ (s, 1H), $8.72(\mathrm{~m}$, $1 \mathrm{H}), 8.47(\mathrm{~m}, 1 \mathrm{H}), 8.35(\mathrm{~m}, 1 \mathrm{H}), 8.18-7.91(\mathrm{~m}, 6 \mathrm{H}), 7.80-7.63(\mathrm{~m}$, $3 \mathrm{H}), 7.49-7.35(\mathrm{~m}, 4 \mathrm{H}), 7.17(\mathrm{~m}, 1 \mathrm{H}), 6.98(\mathrm{~s}, 1 \mathrm{H}), 6.94(\mathrm{~s}, 1 \mathrm{H})$, $6.88(\mathrm{~s}, 1 \mathrm{H}), 6.58(\mathrm{~s}, 1 \mathrm{H}), 4.94(\mathrm{~m}, 1 \mathrm{H}), 4.44(\mathrm{~m}, 4 \mathrm{H}), 4.23(\mathrm{~m}$, $1 \mathrm{H}), 4.03-3.92(\mathrm{~m}, 4 \mathrm{H}), 3.83(\mathrm{~m}, 3 \mathrm{H}), 3.70(\mathrm{~m}, 1 \mathrm{H}), 3.49(\mathrm{~m}, 1 \mathrm{H})$, $3.20(\mathrm{~m}, 5 \mathrm{H}), 2.55(\mathrm{~m}, 1 \mathrm{H}), 2.35(\mathrm{~m}, 7 \mathrm{H}), 1.92(\mathrm{~m}, 1 \mathrm{H}), 1.26(\mathrm{~m}$, $24 \mathrm{H}), 0.35(\mathrm{~d}, 3 \mathrm{H}, J=6.1) .{ }^{13} \mathrm{C}-\mathrm{NMR}\left(75 \mathrm{MHz}, \mathrm{CDCl}_{3}\right): \delta=$ $164.3,164.0,163.7,163.3,163.2,162.4,161.9,161.7,161.4$, $161.0,151.8,150.6,150.2,149.2,145.4,145.0,139.0,138.4$, $137.9,137.7,134.0,133.6,133.4,131.3,131.3,129.1,128.2$, $127.7,127.4,127.0,125.5,125.3,124.1,122.7,122.3,122.2$, 121.8, 121.7, 117.4, 117.2, 117.0, 116.9, 116.5, 116.1, 100.4, 99.8, 99.3, 99.2, 98.2, 97.9, 75.7, 75.6, 75.4, 75.1, 63.2, 58.8, 56.6, 52.1, 51.4, 50.1, 30.3, 29.7, 28.4, 28.3, 28.2, 28.1, 19.5, 19.4, 19.3, 19.2, 14.9. HRMS calculated for $\mathrm{C}_{74} \mathrm{H}_{78} \mathrm{~N}_{10} \mathrm{O}_{12}$ : 1298.5801; found $1299.5878[\mathrm{M}+\mathrm{H}]^{+}$.

Compound 10. Synthesised on a $0.043 \mathrm{mmol}$ scale using the general method described above to yield the title compound as a pale yellow solid (34 mg, 57\%). ${ }^{1} \mathrm{H}-\mathrm{NMR}\left(\mathrm{CDCl}_{3}\right)$ : 12.37 (brs, 1H), $11.95(\mathrm{~s}, 1 \mathrm{H}), 11.79(\mathrm{~s}, 1 \mathrm{H}), 11.73(\mathrm{~s}, 1 \mathrm{H}), 11.25$ (brs, 1H), $8.73(\mathrm{~m}, 1 \mathrm{H}), 8.49(\mathrm{~m}, 1 \mathrm{H}), 8.40(\mathrm{~m}, 1 \mathrm{H}), 8.16-7.96(\mathrm{~m}, 5 \mathrm{H}), 7.76-$ $7.60(\mathrm{~m}, 4 \mathrm{H}), 7.52(\mathrm{~m}, 1 \mathrm{H}), 7.42(\mathrm{~m}, 2 \mathrm{H}), 7.34(\mathrm{~m}, 1 \mathrm{H}), 7.15(\mathrm{~m}$, $1 \mathrm{H}), 6.87(\mathrm{~s}, 1 \mathrm{H}), 6.86(\mathrm{~s}, 1 \mathrm{H}), 6.56(\mathrm{~s}, 1 \mathrm{H}), 5.15(\mathrm{brs}, 1 \mathrm{H}), 4.42$ $(\mathrm{m}, 4 \mathrm{H}), 4.22(\mathrm{~m}, 1 \mathrm{H}), 3.98-3.78(\mathrm{~m}, 7 \mathrm{H}), 3.56(\mathrm{~m}, 1 \mathrm{H}), 3.20(\mathrm{~m}$, $7 \mathrm{H}), 2.98(\mathrm{~m}, 2 \mathrm{H}), 2.54(\mathrm{~m}, 1 \mathrm{H}), 2.32(\mathrm{~m}, 5 \mathrm{H}), 1.86(\mathrm{~m}, 3 \mathrm{H}), 1.24$ $(\mathrm{m}, 24 \mathrm{H}), 0.39(\mathrm{~m}, 3 \mathrm{H}) .{ }^{13} \mathrm{C}-\mathrm{NMR}\left(75 \mathrm{MHz}, \mathrm{CDCl}_{3}\right): \delta=169.7$, $164.3,163.9,163.8,163.2,163.1,162.3,162.0,161.5,160.9$, $152.7,150.0,149.1,145.3,144.7,139.0,138.3,137.5,134.0$, $133.7,133.5,129.8,129.1,128.2,127.8,127.3,126.9,126.1$, $125.5,125.3,124.8,122.7,122.6,122.1,121.7,121.5,117.5$, $117.1,116.7,116.6,116.4,116.0,115.7,100.3,99.9,99.7,98.1$, 97.6, 75.6, 75.3, 75.0, 58.7, 57.6, 56.6, 55.2, 52.1, 30.3, 28.3, 28.2, 28.1, 21.5, 20.7, 19.5, 19.4, 19.3, 19.2, 14.3. HRMS calculated for $\mathrm{C}_{78} \mathrm{H}_{85} \mathrm{~N}_{11} \mathrm{O}_{13}$ : 1383.6328; found 1384.6437 [M + H] $]^{+}$.

Compound 11. Synthesized on a $0.019 \mathrm{mmol}$ (50 mg Wang resin loading $0.38 \mathrm{mmolg}^{-1}$ ) scale, using the general methods previously reported. ${ }^{[18]}$ The crude material was purified by RPHPLC (C18, System E) to afford the title compound as a pale yellow solid (6 mg, 17\%). RP-HPLC (System A): $\mathrm{R}_{\mathrm{t}}=7.58 \mathrm{~min}$. ${ }^{1} \mathrm{H}-\mathrm{NMR}\left(\mathrm{D}_{2} \mathrm{O} / \mathrm{H}_{2} \mathrm{O}\right): 11.17(\mathrm{~s}, 1 \mathrm{H}), 11.12(\mathrm{~s}, 1 \mathrm{H}), 11.03(\mathrm{~s}, 1 \mathrm{H})$, $10.80(\mathrm{~s}, 1 \mathrm{H}), 8.24(\mathrm{~m}, 1 \mathrm{H}), 7.93(\mathrm{~m}, 3 \mathrm{H}), 7.81-7.71(\mathrm{~m}, 6 \mathrm{H}), 7.52$ $(\mathrm{m}, 4 \mathrm{H}), 7.43-7.20(\mathrm{~m}, 5 \mathrm{H}), 7.13(\mathrm{~s}, 1 \mathrm{H}), 7.05(\mathrm{~s}, 1 \mathrm{H}), 6.95(\mathrm{~m}$, $1 \mathrm{H}), 6.46(\mathrm{~s}, 1 \mathrm{H}), 5.85(\mathrm{~m}, 1 \mathrm{H}), 3.39(\mathrm{~m}, 6 \mathrm{H}), 2.92(\mathrm{~m}, 2 \mathrm{H}), 2.74-$ $2.16(\mathrm{~m}, 14 \mathrm{H}), 0.01(\mathrm{~d}, 3 \mathrm{H}, J=6.7)$. HRMS calculated for $\mathrm{C}_{69} \mathrm{H}_{72} \mathrm{~N}_{14} \mathrm{O}_{12}$ : 1288.5454 ; found $1289.5561[\mathrm{M}+\mathrm{H}]^{+}$.

Supporting Information (see footnote on the first page of this article): $\mathrm{CD}$ data, NMR and HPLC-based studies of helix stability, ${ }^{1} \mathrm{H}$ and ${ }^{13} \mathrm{C}-\mathrm{NMR}$ spectra and details of X-ray diffraction experiments.

\section{Acknowledgments}

We would like to thank Dr. B. Kauffmann for diffraction measurements of the $\mathbf{Q}_{\text {Morph }}$ monomer and Dr. Y. Ferrand for assistance in preparing figures for this manuscript. This work was supported by the European Union's Seventh Framework Programme through Marie Curie actions (FP7-IAPP2008-230662-Foldappi, post-doctoral fellowships to S.D. and C.C.) and through the European Research Council (Grant Agreements No. ERC2012-AdG-320892, post-doctoral fellowship to S.D.).

[1] a) H. Yin, A. D. Hamilton, Angew. Chem. Int. Ed. 2005, 44, 4130 4163; b) V. Azzarito, K. Long, N. S. Murphy, A. J. Wilson, Nat Chem. 2013, 5, 161-173; c) B. Baptiste, F. Godde, I. Huc, ChemBioChem. 2009, 10, 1765-1767.

[2] Representative examples: a) C. Branden, J. Tooze in Introduction to Protein Structure, Garland, New York, 1991, pp 1-31. b) J. C. Kendrew, R. E. Dickerson, B. E. Strandberg, R. G. Hart, D. R. Davies, D. C. Philips, V. C. Shore, Nature 1960, 185, 422-427; c) D Seebach, M. Overhand, F. N. M. Kühnle, B. Martinoni, L. Oberer, U. Hommel, H. Widmer, Helv. Chim. Acta. 1996, 79, 913-941; d) D. H. Appella, L. A. Christianson, D. A. Klein, D. R. Powell, X. Huang, J J. Barchi Jr., S. H. Gellman, Nature 1997, 387, 381-384; e) T. Hintermann, K. Gademann, B. Jaun, D. Seebach, Helv. Chim. Acta 1998, 81, 983-1002; f) D. Seebach, M. Brenner, M. Rueping, B. Schweizer, B. Jaun, Chem. Commun. 2001, 207-208; g) V. Semetey, D. Rognan, C. Hemmerlin, R. Graff, J.-P. Briand, M. Marraud, G. Guichard, Angew. Chem. Int. Ed. 2002, 41, 1893-1895; h) A Violette, M. C. Averlant-Petit, V. Semetey, C. Hemmerlin, R Casimir, R. Graff, M. Marraud, J.-P. Briand, D. Rognan, G. Guichard, J. Am. Chem. Soc. 2005, 127, 2156-2164; i) Y. Inai, Y. Ishida, K. Tagawa, A. Takasu, T. Hirabayashi, J. Am. Chem. Soc. 2002, 124, 2466-2473; j) J. Clayden, A. Castellanos, J. Sola, G. A. Morris, Angew. Chem. Int. Ed. 2009, 48, 5962-5965.

[3] One case of spontaneous separation of $P$ and $M$ helices in the solid state has been reported (conglomerate). Yet this would not constitute a preparative separation method and either conformer would racemize again once back in solution. See: H. Zhao, W. Q. Ong, F. Zhou, X. Fang, X. Chen, S. F. Y. Li, H. Su, N.-J. Chob, H. Zeng, Chem. Sci. 2012, 3, 2042-2046.

[4] a) J. Iriondo-Alberdi, K. Laxmi-Reddy, B. Bouguerne, C. Staedel, I Huc, ChemBioChem 2010, 11, 1679-1685; b) E. Gillies, F. Deiss, C. Staedel, J.-M. Schmitter, I. Huc, Angew. Chem. Int. Ed. 2007, 46, 4081-4084.

[5] J. Buratto, C. Colombo, M. Stupfel, S. J. Dawson, C. Dolain, B Langlois d'Estaintot, L. Fischer, T. Granier, M. Laguerre, B. Gallois, I. Huc, Angew. Chem. Int. Ed. 2014, 53, 883-887.

[6] P. S. Shirude, E. R. Gillies, S. Ladame, F. Godde, K. Shin-ya, I. Huc, S. Balasubramanian, J. Am. Chem. Soc. 2007, 129, 11890-11891.

[7] Y. Ferrand, A. M. Kendhale, B. Kauffmann, A. Grélard, C. Marie, V. Blot, M. Pipelier, D. Dubreuil, I. Huc, J. Am. Chem. Soc. 2010, 132, 7858-7859.

[8] N. Delsuc, T. Kawanami, J. Lefeuvre, A. Shundo, H. Ihara, M. Takafuji, I. Huc, ChemPhysChem. 2008, 9, 1882-1890.

[9] T. Qi, V. Maurizot, H. Noguchi, T. Charoenraks, B. Kauffmann, M. Takafuji, H. Ihara, I. Huc, Chem. Commun. 2012, 48, 6337-6339.

[10] a) H. Jiang, C. Dolain, C, J.-M. Léger, H. Gornitzka, I. Huc, J. Am Chem. Soc. 2004, 126, 1034-1035; b) C. Dolain, H. Jiang, J.-M. Léger, P. Guionneau, I. Huc, J. Am. Chem. Soc. 2005, 127, 1294312951 ; c) V. Maurizot, C. Dolain, I. Huc, Eur. J. Org. Chem. 2005, 1293-1301; d) Z. Dong, R. J. Karpowicz Jr, S. Bai, G. P. A. Yap, J. M. Fox, J. Am. Chem. Soc. 2006, 128, 14242-14243; e) C. Li, G.-T Wang, H.-P. Yi, X.-K. Jiang, Z.-T. Li, R.-X. Wang, Org. Lett. 2007, 9, 1797-1800. f) T. Buffeteau, L. Ducasse, L. Poniman, N. Delsuc, I. Huc, Chem. Commun. 2006, 2714-2716; g) L. Ducasse, F. Castet, A. Fritsch, I. Huc, T. Buffeteau, J. Phys. Chem. A 2007, 111, 50925098; h) Q. Gan, F. Li, G. Li, B. Kauffmann, J. Xiang, I. Huc, H. Jiang, Chem. Commun. 2010, 46, 297-299; i) A. M. Kendhale, L. Poniman, Z. Dong, K. Laxmi-Reddy, B. Kauffmann, Y. Ferrand, I. Huc, J. Org. Chem. 2011, 76, 195-200.

[11] a) Z. Dong, G. P. A. Yap, J. M. Fox, J. Am. Chem. Soc. 2007, 129, 11850-11853; b) H.-Y. Hu, J.-F. Xiang, Y. Yang, C.-F. Chen, Org. 
Lett. 2008, 10, 69-72; c) E. Kolomiets, V. Berl, J.-M. Lehn, Chem. Eur. J. 2007, 13, 5466-5479.

[12] Representative examples: a) R. W. Sinkeldam, M. H. C. J. van Houtem, K. Pieterse, J. A. J. M. Vekemans, E. W. Meijer, Chem. Eur J. 2006, 12, 6129-6137; b) J. Recker, D. J. Tomcik, J. R. Parquette, J. Am. Chem. Soc. 2000, 122, 10298-10307; c) A. Tanatani, A Yokoyama, I. Azumaya, Y. Takakura, C. Mitsui, M. Shiro, M. Uchiyama, A. Muranaka, N. Kobayashi, T. Yokozawa, J. Am. Chem. Soc. 2005, 127, 8553-8561; d) M. Kudo, T. Hanashima, A Muranaka, H. Sato, M. Uchiyama, I. Azumaya, T. Hirano, H Kagechika, A. Tanatani, J. Org. Chem. 2009, 74, 8154-8163; e) S. Kohmoto, H. Takeichi, K. Kishikawa, H. Masu, I. Azumaya, Tetrahedron Lett. 2008, 49, 1223-1227.

[13] a) C. Tuerk, L. Gold, Science 1990, 249, 505-510; b) A. D. Ellington, J. W. Szostak, Nature 1990, 346, 818-822.

[14] L. Delaurière, Z. Dong, K. Laxmi-Reddy, F. Godde, J.-J. Toulmé, I. Huc, Angew. Chem. Int. Ed. 2012, 51, 473-477.

[15] a) V. Maurizot, C. Dolain, Y. Leydet, J.-M. Léger, P. Guionneau, I. Huc, J. Am. Chem. Soc. 2004, 126, 10049-10052; b) C. Dolain, J.-M. Léger, N. Delsuc, H. Gornitzka, I. Huc, Proc. Natl. Acad. Sci. U.S.A. 2005, 102, 16146-16151.
[16] P. D. White, W.C. Chan, in Fmoc Solid Phase Synthesis: A Practical Approach (Eds.: W.C. Chan, P. D. White), Oxford University Press, Oxford, 2000, p. 44.

[17] L. Ghosez, B. Haveaux, H. G. Viehe, Angew. Chem., Int. Ed. Engl. 1969, $8,454-455$.

[18] B. Baptiste, C. Douat-Casassus, K. Laxmi-Reddy, F. Godde, I. Huc, J. Org. Chem. 2010, 75, 7175-7185.

[19] Representative examples: a) P. C. Painter, J. L. Koenig, Biopolymers 1976, 15, 229-240; b) B. Perly, Y. Chevalier, C. Chachaty, Macromolecules 1981, 14, 969-975; c) T. A. Keiderling, R. A. G. D. Silva, G. Yoder, R. K. Dukor, Bioorg. Med. Chem. 1999, 7, 133-141 c) A. Mirtič, J. Grdadolnik, Biophys. Chem. 2013, 175-176, 47-53.

[20] E. H. Erickson, L. R. Lappi, T. K. Rice, K. F. Swingle, M. Van Winkle, J. Med. Chem. 1978, 21, 984-988.

[21] T. Qi, T. Deschrijver, I. Huc, Nat. Protoc. 2013, 8, 693-708.

[22] G. A. Morales, J. W. Corbett, W. F. DeGrado, J. Org. Chem. 1998 , $63,1172-1177$.

Received: ((will be filled in by the editorial staff)) Published online: ((will be filled in by the editorial staff)) 


\section{Entry for the Table of Contents}

Controlling the helix handedness of water soluble quinoline-based oligoamide foldamers has been investigated by the installation of chiral end groups at either the $\mathrm{N}$ - or $\mathrm{C}$ terminus. This has respectively afforded either quantitative induction of handedness, or the ability to separate kinetically locked $P$ and $M$ helices as diastereoisomers.
Chirality of Helical Foldamers

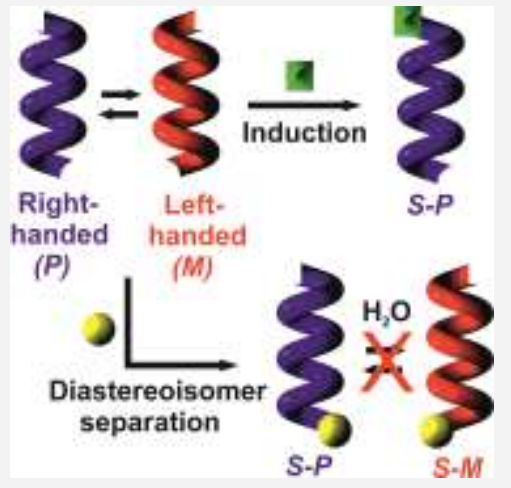

Simon J. Dawson, Ádám Mészáros, Lilla Pethő, Cinzia Colombo, Márton Csékei, András Kotschy* and Ivan Huc*........ Page No. - Page No.

Controlling Helix Handedness in Water Soluble Quinoline Oligoamide Foldamers

Keywords: Quinoline oligoamide foldamers / Chirality /Helix handedness 